\title{
PROPHYLACTIC ROLE OF GLUTATHIONE AND GRANULOCYTE - COLONY STIMULATING FACTOR ON 5-FLUOROURACIL INDUCED MYELOTOXICITY IN MICE
}

\author{
$\mathcal{B} Y^{\prime}$ \\ Essam M. Ali; Seham A. Gad El-Hak; Ibrahim M. El-Shawaf*; \\ -) \\ Mohamad M. Salama \\ De'parmests of Forchsic Medicine and Clinical Toxicology and Paihology*. \\ 2Fachify of Medicise, Mansoura University. Egypt
}

\begin{abstract}
The protective effect of glutathione (GSH) and granulocyle colony stimulating factor (G-CSF) on myelosnppression induced by 5-flnorouracil (5-FU) were compared in fenale mice. The aninals were divided into seven groups. Group I (10 mice) received no treatment, group 2 (10 mice) received GSH ( $800 \mathrm{mg} /$ $\mathrm{kg}$ ) by intaperitoneal route in daily doses for the first 7 days then left untreated for another 7 days, and group . $3(10$ mice $)$ received G.CSF $(250 \mu \mathrm{g} / \mathrm{kg})$ by subcutaneous route in daily doses for the first 7 days then left mureated for another 7 days. Animals in groups 1, 2 and 3 were sacrificed on day 15. Group 4 (20 mice) received a single dose of $5 . F U(160 \mathrm{mg} / \mathrm{kg})$ by intraperisoneal route in the $8^{\text {th }}$ day. Group $S$ (20) mice) received GSH in daily doses for the first 7 days followed by a single dose of .5.FU in the $8^{\text {th }}$ day. Group 6 (20 mice) received G-CSF in daily doses for the firsi 7 days followed by a single dose of $S$. FU in the $8^{\text {th }}$ day and groitp 7 of animals $(20$ mice) received daily doses of both GSH and G.CSF for. the first 7 days followed by a single dose of $5 . F U$ in the 8hin day. Animals in groups 4, 5, 6 and 7 were divided into 2 subgroups; subgroup a: 10 mice were sncrificed on day 9 i.e. I day after S.FU adminismtion and subgroup b: 10 mice were sacrificed on day 15 i.e. I week afier 5-FU administration. Mice were' sacrificed by cut throat and biood saimples were obtained for determination of haematological values; hacmoglobin $(H 6)$, haematocrite value (HCT), meam conpuscular haemoglobin concentration (MCHC). mean corpiescular volume (MCV), mean corpuscular haemoglobin (MCH), as well as total (TLC) and dif. ferintial (DLC) lencocyle count. Then dissection of mice was done where the right femurs were used for bome murrow cyology, while lefi femurs sverc used for bone marrow hisiopathology. In groups Sa given GSH pretreament and 6a given G.CSF pretreatment (where mice killed / day afier 5.FU dose) protection was demonstrated regarding nestropenia, bone marrow cytology and histopathology. Incomplete protection was revealed in mice received GSH pretreatment or G-CSF pretreatnent and killed / iveck of. ter 5.FU dose (groups 56 and 6 b respectively), while groups $7 a$ and $7 b$ given combined GSH and G.CSF pretreatment revealed no protection.
\end{abstract}




\section{INTRODUCTION}

There are two major types of systemic cancer therapy : chemotherapy and biologic therapy. Cancer chemotherapeutic agents are usually discuissed in groups that reflect either the origin of the drug or their predominant mechanism of acti: :a. The major classes of agents include the alkylating agents, antitumor antibiotics, plant alkaloids, antimetabolites, hormonal agonists and antagonists (Haskell, 1995).

Antimetabolites are antineoplastic agents that are structurally and chemically similar to naturally occurring compounds required for synthesis of purines, pyrimidines, and nucleic acids. Antimetabolites must be present at cytotoxic concentrations during DNA synthesis to be effective and thus tend to be cell cycle S-phase specific drugs (Richard,1992 ).

5-fluorouracil (5-FU), is an antimetabolites, anticancer agent which is used as an essential part for the treatment of wide range of solid tumors. It has antitumor activity against epithelial malignancies arising in the gastrointestinal tract, breast as well as the head and neck (Malet-Martino and Martino, 2002). As all the anticancer agents, 5-FU leads to several toxicities. Myelotoxicity is the major toxic effect in patients receiving bolus doses (Takimoto and Page, 2004).
The haemopoietic growth factor ( granulocyte-colony stimulating factor G-CSF) was proved to shorten the duration and decrease the severity of chemotherapy induced neutropenia (Liang, 2003).

Lamson and Brignall, (2000) demonstrated the cytoprotective effect of glutathione (GSH) against chemotherapeutic agents. Kojima et al.(2003) suggested that glutathione could prevent the 5-FUinduced haemopoietic toxicities and accelerate recovery from such toxicities.

Cascinu et al.(1997) have used a combination of both G-CSF and glutathione with intensive regimen of 5-FU, cisplatin and epi-doxorubicin in advanced gastric cancer, and they confirmed high activity of the regimen, with acceptable toxicity.

The aim of the present study is to compare the protective effect of glutathione, granulocyte colony stimulating factor or both on 5-fluorouracil induced myelotoxicity in mice.

\section{MATERIAL AND METHODS}

\section{Drugs :}

5-fluorouracil (5-FU) $5 \mathrm{ml}$ ampoules each contains 250mg 5-FU (Biosyn Arzneimittel GmbH Fellbach, Germany). 5-FU was diluted with distilled water to give a final concentration of $10 \mathrm{mg} / \mathrm{ml}$. It was given in a dose $160 \mathrm{mg} / \mathrm{kg}$ by intraperito- 
neal route (Friberg et al.,2000).

L-Glutathione reduced (GSH) powder, $5 \mathrm{gm} /$ bottle (SIGMA-ALDRICH,Inc) wàs obtained from Egyptian International Certter Importer Cairo, Egypt. It was stored in the refrigerator. GSH was dissolved in distilled water to give a final concentration of $80 \mathrm{mg} / \mathrm{ml}$. It was given in a dose $800 \mathrm{mg} /$ $\mathrm{kg}$ by intraperitoneal route (Kojima et âl., 2003).

Filgrastim Neupogen (GranulocyteColony Stimulating Factor "G-CSF") $0.5 \mathrm{ml}$ prefilled syringe of $300 \mu \mathrm{g} / \mathrm{ml}$ concentratiôn (F.Hoffmann La Roche Ltd, Basel, Switzerland). It was stored in the refrigerafor." G-CSF was diluted with distilled water to give a final concentration of $10 \mu \mathrm{g} /$ $\mathrm{ml}$. It was given in a dose $250 \mu \mathrm{g} / \mathrm{kg}$ by subcutaneous route (Lord et al., 2001).

\section{Animals:}

The study was carried out on 110 adult female mice with their weight ranged 27$32 \mathrm{gm}$ obtained from the Animal House of Mansoura Faculty of Pharmacy. Mice were chosen all fernales to alleviate the gender effect on the results (Doeing et al ., 2003). The mice were housed in metallic cages, led a standard diet and allowed unlimited access to food and water under standard laboratory conditions. After a week of acclimatization to the housing conditions the mice were divided into seven groups housed in separate cages. The duration of the study was 15 days during which mortality among mice was recorded.

Group 1 of animals (10 mice) received no treatment and served as control group, group 2 (10 mice) received GSH ( $800 \mathrm{mg}$ / $\mathrm{kg}$ ) by intraperitoneal route in daily doses for the first 7 days then left untreated for another 7 days, and group 3 (10 mice) received G-CSF $(250 \mu \mathrm{g} / \mathrm{kg}$ ) by subcutaneous route in daily doses for the first 7 days then left untreated for another 7 days. Animals in groups 1,2 and 3 were sacrificed on day 15. Group 4 (20 mice) received a single dose of 5 -FU (160 mg/ kg) by intraperitoneal route in the 8 th day, Group 5 (20 mice) received GSH in daily doses ( $800 \mathrm{mg} / \mathrm{kg}$ by intraperitoneal route) for the first 7 days followed by a single dose of 5-FU (160 mg/ $\mathrm{kg}$ by intraperitoneal route) in the 8 th day, Group 6 (20 mice) received G-CSF in daily doses $(250 \mu \mathrm{g} / \mathrm{kg}$ by subcutaneous route) for the first 7 days followed by a single dose of 5-FU (160 $\mathrm{mg} / \mathrm{kg}$ by intraperitoneal route) in the 8 th day and group 7 of animals ( 20 mice) received daily doses of both GSH $(800$ $\mathrm{mg} / \mathrm{kg}$ by intraperitoneal route) and GCSF ( $250 \mu \mathrm{g} / \mathrm{kg}$ by subcutaneous route) for the first 7 days followed by a single dose of 5 -FU (160 mg/ kg by intraperitoneal route) in the 8 th day. Animals in groups $4,5,6$ and 7 were divided into 2 subgroups ; subgroup a (10 mice) in which animals were sacrificed on day 9 i.e. 1 day 
after 5-FU administration and subgroup b (10 mice) in which animals were sacrificed on day 15 i.e. 1 week after 5-FU administration. Mice were sacrificed by the cut throat method.

\section{Samples collection:}

Blood samples ( $2 \mathrm{ml}$, each) were collected in EDTA tubes from the mice cut throats after sacrification. The samples were obtained from animals of subgroups $4 a, 5 a, 6 a$ and $7 a$ on day 9 from start of study. The rest of the samples were obtained from animals of groups 1,2,3 and subgroups $4 \mathrm{~b}, 5 \mathrm{~b}, 6 \mathrm{~b}$ and $7 \mathrm{~b}$ on day 15 from the start of study.

The following haematological values were determined ; haemoglobin ( $\mathrm{Hb}) \mathrm{g} /$ dl, mean corpuscular haemoglobin concentration (MCHC) g/dl, mean corpuscular volume (MCV) Fl (femoliter)', mean corpuscular haemoglobin (MCH) Pcg (piclogram) measured according to the method of Riedinger and Rodak (1998), haematocrite value (Hct) \% measured by microhaematocrit method (Dill and Costill,1974) as well as total (TLC) and differential (DLC) leucocyte count measured according to the method of England and Bain (1976),

After blood sampling, animals were dissected to obtain both femoral bones. The right one was used for bone marrow cytology according to the method of Koji- ma et al., (2003), while the left one was used for histopathology according to the method of Anderson and Bancroft, (2002).

\section{Statistical analysis:}

Statistical analysis of data was done by using Excel program (Office 2000) and SPSS (Statistical Package of Social Science), Windows 98, computer compatible IBM. The first part of data analysis was descriptive. The mean \pm S.D. were used for description of frequency.

The second part of the analysis was analytic: For quantitative data. Student's t test was used for comparison between two groups. Anova t test was used for comparing more than two groups followed by Post-Hoc test for testing the significant different one. For qualitative data KruskalWallis test was used for comparing more than two groups. $P$ value was considered significant if $<0.05$.

\section{RESULTS}

I) Haematological parameters and bone marrow cytology: Table (1)

As regards TLC and bone marrow cytology it was found that groups 3 ( received G.CSF), and 6a (received G-CSF before 5-FU and killed 1 day later) have higher (i.e. better) values than the control, while other groups have lower values (i.e. worse ). TLC was higher also in group $5 a$ 
(received GSH before 5-FU and killed 1 day later) than the control. The peripheral leukopenia and medullary myelosuppression in this study are detected in mice received 5-FU either alone or with pretreatment of combined GSH and G-CSF and increased with progression of time. So, mice received 5-FU and killed after 1 week showed more myelosuppression than those received the same treatment but killed after 1 day.

No significant difference was detected between the studied groups as regards $\mathrm{Hb}, \mathrm{HCT}, \mathrm{MCHC}, \mathrm{MCV}$, and $\mathrm{MCH}$.

Regarding the differential leucocytic count (DLC) it was noticed that neutrophils of all groups have lower percentages (i.e. worse) than the control whereas Iymphocytes of all groups have higher percentages (i.e. worse) than the control. In addition groups 3,6 a (received G-CSF before 5-FU and killed 1 day later) and $7 \mathrm{~b}$ (received combined GSH and G-CSF before 5-FU and killed 1 week later) showed higher eosinophil percentage than the control, while other groups showed lower eosinophil percentage than contrnl. For monocytes percentage, the results of the present study showed that it was significantly lower in group 3 and insignificantly lower in all other groups when compared with control group. Basophils were nut detected in control group and in both group $5 b$ (received GSH before 5-FU and killed 1 week later) and $6 \mathrm{~b}$ (received G-CSF before 5 -FU and killed 1 week later). The basophils percentage in group 3 (received GCSF) was significantly higher compared to group 2 (received GSH) .

As regards mortality rates among the studied mice no deaths were recorded in groups 1, 2, 3, 4a, 5a, 6a and 7a. The highest mortality rate $(70 \%)$ was observed in both group $4 \mathrm{~b}$ (received 5-FU only) and $7 \mathrm{~b}$ (received combined GSH and G-CSF before 5-FU and killed 1 week later) followed by group $6 \mathrm{~b}$ (received G-CSF before 5-FU and killed 1 week later) (60\%), then group $5 \mathrm{~b}$ (received GSH before 5 -FU and killed 1 week later) (50\%):

Comparison of haematological parameters and bone marrow cytology in mice of groups 4a, 5a, 6a and $7 a$ showed no significant differences between the groups in all the compared parameters except TLC and bone marrow cytology which was significantly higher in groups $5 \mathrm{a}$ and $6 \mathrm{a}$ versus group $4 \mathrm{a}$ and significantly lower in group $7 \mathrm{a}$ versus groups $5 \mathrm{a}$ and $6 \mathrm{a}$ (Table 3 ).

Comparison of haematological parameters and bone marrow cytology in mice of groups $4 \mathrm{~b}, 5 \mathrm{~b}, 6 \mathrm{~b}$ and $7 \mathrm{~b}$ showed no significant differences between the groups in all the compared parameters except the bone marrow cytology which was significantly higher in group $6 \mathrm{~b}$ versus group $4 \mathrm{~b}$ and 
significantly lower in group $7 \mathrm{~b}$ veisus group 6b (Table 4).

Comparison of haematological parameters and bone marrow cytology in mice of groups 4b, 5b, 6b and 7b (killed 1 week after receiving drugs) versus mice of groups 4a, 5a, 6a and 7a (killed 1 day after receiving drugs) showed no significant differences except significantly lower TLC and bone marrow cytology in group $5 \mathrm{~b}$ versus group $5 \mathrm{a}$ and group $6 \mathrm{~b}$ versus group $6 a$, significantly lower neutrophils percentage in group $4 \mathrm{~b}$ versus group $4 \mathrm{a}$ and group $7 \mathrm{~b}$ versus group $7 \mathrm{a}$ and significantly higher lymphocytes percentage in group $4 \mathrm{~b}$ versus group $4 \mathrm{a}$ (Table 5).

II) Histopathological findings in bone marrow :

Mice of groups (1, 2, 3, 4a, 5a, 6a and 7a) show no abnormal histopathological findings. Histopathological findings characteristic to 5-FU (hypocellularity, dilated sinusoids, interstitial haemorrhage, increased fat content and interstitial fibrosis) are detected only in groups $4 b, 5 b, 6 b$ and $7 \mathrm{~b}$.

The survived mice of group $4 \mathrm{~b}$ show severe hypocellularity and dilated sinusoids. Two of them show increased megakaryocytes, one shows decreased megakaryocytes (Figure 1), one shows increased fat content and interstitial haemorrhage (Figure
2) and one shows interstitial fibrosis (Figure 3).

In group $5 \mathrm{~b}$ two out of the five $(40 \%)$ of survived mice reveal mild hypocellularity , dilated sinusoids and interstitial haemorrhage. One of them has increased megakaryocytes and the other has decreased megakaryocytes (Figure 4). The other three mice show normal histopathological findings.

In group $6 \mathrm{~b}$ two of the survived four mice $(50 \%)$ have mild hypocellular bone marrow. One of them shows interstitial haemorrhage and increased megakaryocytes (Figure 5), while the other one shows decreased megakaryocytes .

In group $7 \mathrm{~b}$ all the three survived mice have severe hypocellular bone marrow. Two of them have dilated sinusoids and increased megakaryocytes (Figure 6) and one mouse has increased fat content and interstitial haemorrhage.

\section{DISCUSSION}

5-fluorouracil has been used for the treatment of colorectal, breast and head/ neck cancer for more than 40 years and is the most commonly prescribed chemotherapeutic agent (Dobritzsch et al.,2001). Chemotherapy-induced neutropenia, the primary dose-limiting toxicity of most cancer chemotherapy agents, is associated 
with numerous negative consequences, including life-threatening infections (Dale, 2003).

Glutathione is a naturally occurring endogenous antioxidant that is cytoprotective. Thus, treatment with glutathione or its precursors may protect normal cells during cancer chemotherapy (Doolittle et al.,2002). Priming has been defined as the administration of a colony stimulating factor prior to chemotherapy. There are several theoretical reasons why this schedule of administration may prove to be advantageous (Lowenberg et al., 2003).

In the present study, the insignificant differences of TLC, DLC, $\mathrm{Hb}$ level, blood indices and bone marrow cytology in mice received Glutathione when compared with the contol group are in agreement with the study of Kojima et al. (2003).

In the present study, higher TLC values detected in mice received G-CSF than mice of the control group is in agreement with the results of Lord et al. (2001) who suggested that significantly increased TLC values in normal mice given G-CSF reflects its stimulant effect on neutrophils granulopoiesis. The significantly lower neutrophils percentage in these mice received G-CSF than the control group can be explained by the finding of Takatani et al. (1996) who found that levels of G-CSF in serum are inversely correlated with cir- culating neutrophils count. Thereby stoppage of G-CSF after the seventh day combined with increased neutrophils count at this time will lead to increase G-CSF elimination with decreased endogenous G-CSF level leading to fall of neutrophils percentage below the normal level.

In this study peripheral leukopenia and medullary myelosuppression detected in mice received 5-FU either alone or with pretreatment of combined GSH and GCSF is in accord with the work of Friberg et al. (2000). The increased leukopenia and myelosuppression with progression of time noticed in the current study is in agreement with the results of Colombo et al. (2001) who found that the time of major depression for granulocytes after 5-FU was in day 7-14 in humans.

The chemoprotective effect of GSH in mice received GSH pretreatment before 5FU and killed after 1 day is observed from absence of leukopenia or medullary myelosuppression denoting complete chemoprotection against 5-FU effect on bone marrow. These results are supported by the works of Cascinu et al. (1997) and Kojima et al. (2003).

In contradiction to these findings were the results of lerza et al. (1986) and Doyle et al. (1993) which showed failure of thiol antioxidants to protect peripheral blood elements in mice from the massive de- 
crease following chemotherapy. This could be attributed to the high dose needed for chemoprotection. This explanation was supported by Prasad (2004), who stated that antioxidants are needed in high dose to be used in adjunct to chemotherapy.

Proposed mechanisms for GSH induced chemoprotection include: (1) combination of GSH with anticancer drugs to form less toxic and more water soluble GSH conjugate , (2) antioxidant and free-radical scavenging activity (Zhang et al.,1998), (3) DNA repair (Chen and Zeller,1991), (4) pumping toxic chemotherapeutics out of cells via the multidrug resistanceassociated proteins (Barrand et al., 1997) and (5) decrease proliferation and differentiation of myeloid cells (Gate et al., 2004) decreasing their susceptibility to chemotherapeutic agents acting on rapidly dividing celis (De Haan et al., 1996).

Leukopenia and medullary myelosuppression detected in mice received $\mathrm{GSH}$ pretreatment before 5-FU and killed after 1. week denote incomplete protection. A possible explanation is that chemoprotection is maximally effective if continued during and after chemotherapy treatment as in the study of Danysz et al. (1984).

The complete chemoprotective effect of G-CSF in mice received G-CSF pretreatment before 5-FU and killed after 1 day is noticed from absence of leukopenia or medullary myelosuppression. This finding is in agreement with that of Brockstein et al. (2000) and Danforth et al. (2003).

In contrast to these results were those obtained by Gardner et al. (2003) who found that pretreatment with haematopoietic growth factors lead to bone marrow failure after administration of chemotherapeutic agents.

In another study done by Harrison et al.(1994) it had been shown that 5-FU was able to abolish the increased numbers of primitive cells in the spleen, induced by haematopoietic growth factors administration to mice, if it was given in the middle of the 7 th day haematopoietic growth factors treatment period. However, if it was administered at day 8, many stem cells had lost vulnerability to 5-FU.

Incomplete chemoprotection in mice received G-CSF pretreatment before 5-FU and killed after 1 week is denoted by presence of leukopenia and medullary myelosuppression. This result is in accord with the study of De Haan et al. (1996) where haematopoietic growth factors pretreatment could not abolish the period of major leucocytes depression in mice.

The proposed mechanism of efficacy of G CSF pretreatment is the increased numbers of haematopoietic cells present before 
chemotherapy administration. In addition, enhanced number of primitive and progenitor cells may result in reduced cycling activity, i.e. 5-FU sensitivity of these cells, due to normal physiological feed back loops (De Haan et al., 1996). The second proposed mechanism shows the importance of spacing between HGFs administration and chemotherapy administration. Time is needed until reflex inhibition of proliferation of cells occur and not exposing the cells during rapid division phase to the chemotherapeutic agent.

The combined pretreatment with GSH and G-CSF reveal no protection at all either in mice killed 1 day after 5-FU or those killed 1 week after 5-FU denoted by presence of leukopenia and medullary myelosuppression in both groups.

These results could be explained by the work of Sattler et al. (1999). They found that haematopoietic grow th factors signals through the formation of reactive oxygen species (ROS) and that antioxidants e.g. Nacetyl cysteine reduced growth and viability of cells.

Also Gate et al. (2004) have shown that G-CSF was more effective at stimulating proliferation of haematopoietic cells in glutathione transferase (GST) deficient mice than in wild type. This is explained by the fact that GST interacts with and suppresses $\mathrm{C}-\mathrm{Jun}$ NH2-terminal kinase [an enzyme which is responsible for increased myeloproliferation].

Cascinu et al. (1997), however contradict these findings and this could be explained by the fact that there was a separation between G-CSF and GSH as regards days of administration which could prevent the antagonism between them.

In the present study significantly higher monocytes percentage is observed in mice received G- CSF pretreatment before 5-FU and killed 1 day later versus mice received G-CSF only. This observation coincides with the findings of Gabrilove (1991). The significant decrease of monocytes percentage in mice received G-CSF versus the control group can be attributed to the fact that G-CSF level has fallen following stoppage of administration due to increased clearance by high neutrophils count which in turn will lower the monocytes percentages.

The insignificant differences detected between the studied groups as regards $\mathrm{Hb}, \mathrm{HCT}, \mathrm{MCHC}, \mathrm{MCV}$, and $\mathrm{MCH}$ denote absence of RBCs affection to which can be explained by comparing the half life of granulocytes (6-8 hours) to that of RBCs (120 days). This fact shows why the myelosuppressive drugs need longer time for producing anaemia than the time needed for neutropenia (Hoagland, 1992). 
Although occurrence of deaths can be considered a drawback, however it should be put in mind that in clinical trials made on humans the complete sterile environment is difficult to be obtained specially in outpatient treatment which makes secondary infection, and not neutropenia itself, the major cause of death in humans (Dale, 2003). This could be explained by the association between increased mortality rate in mice with higher degree of neutropenia in groups $4 \mathrm{~b}$ and $7 \mathrm{~b}$.

Histopathological findings characteristic to 5-FU (hypocellularity, dilated sinusoids, interstitial haemorrhage, increased fat content and interstitial fibrosis ) are detected only in groups $4 b, 5 b, 6 b$ and $7 b$. Absence of these findings in the other groups could be explained by the work of D'souza and Narayana (2002) who found that cytotexic drug induced myelotoxicity after 24 hours was in the form of apoptosis and the damaged cells appeared as darkly stained bcdies in the marrow. The presence of these cells can be detected by cytological smears, while histopathological examination cannot differentiate apoptotic cells from normal ones.

GSH can be given concurrently with chemotherapy (Kojima et al., 2003) or even after chemotherapy (Neuwelt et al., 2004), so, potentiating its protective effect. In addition GSH is a cytoprotective agent where its action is not only on bone marrow, but affecting many systems owing to its detoxifying capabilities (Doolittle et al.,2002). On the contrary haematopoietic growth factors cannot be given during the chemotherapeutic course as this will result in fatal bone marrow aplasia (Weiss and Lackman, 2002) and its protective effects are believed to be on the bone marrow only (Liang, 2003).

It can be concluded from this work that chemoprotection of GSH, do not progress to the end in mice killed one week after 5 FU dose and this can be attributed to the fact that chemoprotection is maximally effective if continued during and after chemotherapy treatment.

It can be also concluded that G-CSF pretreatment produce complete protection only in mice killed one day after 5-FU dose. This chemoprotective effect is diminished as the study proceeded in mice killed one week after 5-FU dose denoting that pretreatment combined with posttreatment of G-CSF would offer better results. 
Table (1): Haematological parameters abd bone inarow cysologey in ill studied groups

\begin{tabular}{|c|c|c|c|c|c|c|c|c|c|c|c|c|}
\hline \multirow{2}{*}{ Groups } & \multirow{2}{*}{$\begin{array}{l}\text { ls.M.cytols } \\
\text { gy (inum') }\end{array}$} & \multirow{2}{*}{$\begin{array}{c}1 \text { lib } \\
(y / \mathrm{d} 1)\end{array}$} & \multirow{2}{*}{$\begin{array}{l}\text { IICT } \\
(\%)\end{array}$} & \multirow{2}{*}{$\begin{array}{c}\text { ALCHC } \\
(\%)\end{array}$} & \multirow{2}{*}{$\begin{array}{l}M C V \\
\text { (I) }\end{array}$} & \multirow{2}{*}{$\begin{array}{l}\text { Nic:l } \\
\text { (stca) }\end{array}$} & \multirow{2}{*}{$\underset{\left(/ m+s^{3}\right)}{\operatorname{Tlc}}$} & \multicolumn{5}{|c|}{$1) \mid(C(m)$} \\
\hline & & & & & & & & Neutrogplails & tympituryten & limsinophils & Atanocyles & Bassyphils \\
\hline I Control & $\begin{array}{l}1978.5 \pm \\
130.959\end{array}$ & $\begin{array}{c}12.9 .13 \pm \\
0.966\end{array}$ & $\begin{array}{c}37.609 \pm \\
2.994\end{array}$ & $\begin{array}{r}32.727 \\
+0.6999 \\
\end{array}$ & $\begin{array}{r}49.872 \\
+0.6+44 \\
\end{array}$ & $\begin{array}{c}32.51 .3 \\
0.981\end{array}=$ & $\begin{array}{c}3810 \pm \\
685.48-4\end{array}$ & $\begin{array}{l}\text { Gil.S. } \\
\text { S.A.5n }\end{array}$ & $\begin{array}{l}34.3^{3} \pm \\
9.654\end{array}$ & $\begin{array}{l}1.6 \pm 5 \\
1.50 .5\end{array}$ & $\begin{array}{l}3.5 \pm \\
2.22 .3\end{array}$ & $4 \pm 0$ \\
\hline $\begin{array}{l}2 \\
\text { GSH1 }\end{array}$ & $\begin{array}{l}1852.5 \div \\
208.952\end{array}$ & $\begin{array}{c}11.117 \pm \\
1.361\end{array}$ & $\begin{array}{c}34.25 i \\
4.221\end{array}$ & $\begin{array}{r}32.514 \\
+0.307\end{array}$ & $\begin{array}{r}511.25 ! \\
\pm 0.952\end{array}$ & $\begin{array}{c}31.74 x= \\
1.121\end{array}$ & $\begin{array}{c}3.3(4) \pm \\
1293.57\end{array}$ & $\begin{array}{l}5.3 .3 \pm \\
8.731\end{array}$ & $\begin{array}{l}42.5 \pm \\
8,754\end{array}$ & $\begin{array}{l}1.1 \pm \\
0.7 .37\end{array}$ & $\begin{array}{l}2.7 \pm \\
0.4 \pm 5\end{array}$ & $0.4 \pm 1$ \\
\hline G.CSF & $\begin{array}{l}23: 5 \pm \\
554.000\end{array}$ & $\frac{12.181}{1.29}=$ & $\begin{array}{l}38.198 \pm \\
-6079\end{array}$ & $\begin{array}{r}32.241 \\
+0.091 \\
\end{array}$ & $\begin{array}{r}50.661 \\
+2.618 \\
\end{array}$ & $\underset{0.5 \div 5}{31.524}=$ & $\begin{array}{l}6950= \\
2 \times 67.53 \times\end{array}$ & $\begin{array}{l}i 5.6 \div \div \\
10.243\end{array}$ & $\begin{array}{l}50.4 \div \\
9.755\end{array}$ & $1.7 \div$ & $\begin{array}{l}1.4 \pm \\
0.845\end{array}$ & $\begin{array}{l}0.9+1 \\
0.567\end{array}$ \\
\hline $4 a$ & $\begin{array}{r}1217 \pm \\
288.253\end{array}$ & $\begin{array}{c}10.328 \\
2.1 .50\end{array}$ & $\begin{array}{c}31.175= \\
6.011\end{array}$ & $\begin{array}{r}32.927 \\
+2.702 \\
\end{array}$ & $\begin{array}{r}+9.971 \\
+6.564 \\
\end{array}$ & $\begin{array}{c}30.36 \pm \\
1.65 .5\end{array}$ & $\begin{array}{l}19811 \pm \\
(1)(1,0 \leqslant n\end{array}$ & $\begin{array}{l}51 \pm \\
+.320\end{array}$ & $\begin{array}{l}53.2 \pm \\
5.412\end{array}$ & $\begin{array}{l}1.1 \leq \\
0904\end{array}$ & $\begin{array}{l}1.9 \pm \\
0.575\end{array}$ & $\begin{array}{l}0.5 \frac{3}{2} \\
0.788\end{array}$ \\
\hline $5 a$ & $\begin{array}{l}19.5 \pm \\
302.994\end{array}$ & $\begin{array}{c}11.851 \\
1.226\end{array}$ & $\begin{array}{c}35.582= \\
3.171\end{array}$ & $\begin{array}{r}33.267 \\
\pm .3 .466 \\
\end{array}$ & $\begin{array}{r}77.0940 \\
+46.57\end{array}$ & $\begin{array}{l}79.0 .3 \pm \\
2.568\end{array}$ & $\begin{array}{l}\sqrt{170 \pm} \\
1310.582\end{array}$ & $\begin{array}{l}5+.1 \pm \\
6 . .3 \times-4\end{array}$ & $\begin{array}{l}41.7 \pm \\
6.81 .5\end{array}$ & $\begin{array}{l}1.2 \pm \\
1.0 .32\end{array}$ & $\begin{array}{l}2.7 \pm \\
0.9 \pm 5\end{array}$ & $\begin{array}{l}0.3 \pm \\
0.674\end{array}$ \\
\hline 6.9 & $\begin{array}{r}2172 \pm \\
2.33 .942\end{array}$ & $\begin{array}{c}11.871 \pm \\
2.1 .57\end{array}$ & $\begin{array}{c}36.851 \pm \pm \\
6 .(1), 9\end{array}$ & $\begin{array}{r}31.735 \\
+2.811 \\
\end{array}$ & $\begin{array}{r}46.512 \\
+5.14 .4\end{array}$ & $\begin{array}{c}29.232 \pm \\
2.365\end{array}$ & $\begin{array}{l}2(170) \pm \\
1(x) 5,40,5\end{array}$ & $\begin{array}{l}54.5 \pm \\
6.587\end{array}$ & $510.4 \pm$ & $\frac{2+4}{1.1054}$ & $\begin{array}{l}2.5 \pm \\
1.1003\end{array}$ & $\begin{array}{l}0.6 \pm \\
18.649\end{array}$ \\
\hline 73 & $\begin{array}{l}1273 \pm \\
191.5=6\end{array}$ & $\begin{array}{l}9.83611) \pm \\
2.1 .35\end{array}$ & $\begin{array}{c}39.5112= \\
5.919\end{array}$ & $\begin{array}{r}32.861 \\
\pm 1.752 \\
\end{array}$ & $\begin{array}{r}+8.142 \\
\pm 7.401\end{array}$ & $\begin{array}{c}36.225 \pm \\
2.351\end{array}$ & $\begin{array}{l}1975 \pm \\
\text { (9) } 924\end{array}$ & $\begin{array}{l}51.7 \pm \\
7.958\end{array}$ & $\begin{array}{l}46.7= \\
7.546\end{array}$ & $\begin{array}{l}0.9 \pm \\
0.875\end{array}$ & $\begin{array}{l}2.4 \pm \\
1.264\end{array}$ & $\begin{array}{l}0.3 \pm \\
0.48 .3\end{array}$ \\
\hline $4 h$ & $\begin{array}{c}873.333 \pm \\
40.414\end{array}$ & $\begin{array}{c}11.12 \pm \\
1.996\end{array}$ & $\begin{array}{c}3.4665 \\
6.189\end{array}$ & $\begin{array}{c}32.19 \pm \\
0.103\end{array}$ & $\begin{array}{r}51.633 \\
+4.428 \\
\end{array}$ & $\begin{array}{c}31.753 \pm \\
0.492\end{array}$ & $\begin{array}{c}756 \pm \\
50\end{array}$ & $\begin{array}{c}3+.6(6) t 1 \pm \\
+\ldots .5(x)\end{array}$ & $\begin{array}{l}61 \pm \\
1.582\end{array}$ & $T \pm 11$ & $\begin{array}{l}\text { I.forfit }= \\
1.154\end{array}$ & $\begin{array}{l}1.660= \\
1154\end{array}$ \\
\hline Si) & $\begin{array}{r}1310 \pm \\
334.757\end{array}$ & $\begin{array}{c}9.582 \pm \\
0.869\end{array}$ & $\begin{array}{c}30.541 \\
2.857\end{array}$ & $\begin{array}{r}32.394 \\
+0.302 \\
\end{array}$ & $\begin{array}{r}49.754 \\
+0.457\end{array}$ & $\begin{array}{c}32.515 \pm \\
0.302\end{array}$ & $\begin{array}{l}1230 \pm \\
5+2.67 \mathrm{~S}\end{array}$ & $\begin{array}{l}44.4 \pm \\
10.4 .54\end{array}$ & $\begin{array}{l}5.2 \pm \\
9.628\end{array}$ & $\begin{array}{l}0.3 \pm \\
0.836\end{array}$ & $\begin{array}{l}2.6 \pm \\
1.516\end{array}$ & $0 \pm 0$ \\
\hline 60 & $\begin{array}{c}1568.75 \pm \\
391.245 \\
\end{array}$ & $\begin{array}{c}10.695 \pm \\
1.63 .5\end{array}$ & $\begin{array}{c}30.26 .3 \pm \\
6.0 \times 3.3\end{array}$ & $\begin{array}{r}31.318 \\
+1.682 \\
\end{array}$ & $\begin{array}{r}52.375 \\
+4.158 \\
\end{array}$ & $\begin{array}{c}30.455 \pm \\
1.93 \times\end{array}$ & $\begin{array}{l}1575 \pm \\
165,5 \pm 4\end{array}$ & $\begin{array}{l}76.75 \pm \\
9 .(606)\end{array}$ & $\begin{array}{l}54.5 \pm \\
\$ .426 \\
\end{array}$ & $\begin{array}{l}10.75 \pm \\
0.957\end{array}$ & $\begin{array}{c}1.75 \pm \\
0.5\end{array}$ & $\theta \pm 0$ \\
\hline 71) & $900 \pm 100$ & $\begin{array}{l}\left.10.6^{9}\right) \pm \\
0.550^{-1}\end{array}$ & $\begin{array}{r}39.333= \\
7.160\end{array}$ & $\begin{array}{c}32.22 \pm \\
0.051\end{array}$ & $\begin{array}{c}47.5315 \\
4.291\end{array}$ & $\begin{array}{l}30.19 \pm \\
1.76 \mathrm{i}\end{array}$ & $\begin{array}{l}\text { 866.666 } \pm \\
\text { 305.505 }\end{array}$ & $\begin{array}{c}.4 .666 \pm \\
2.0851\end{array}$ & $60 \pm 2$ & $\frac{2.333 \pm}{0.517}$ & $2 \pm$ & $1 \pm !$ \\
\hline
\end{tabular}

4a 5-FU killed after I day, 5a 5-FU + GSH killed after I day, 6a 5-FU + G-CSF killed alier I day. 7:a 5-FU + GSH + G-CSF killed after I day.

4b 5-FU killed after 1 week. 5b 5-FU +GSH killed after I weck. 6b 5-FU +G-CSF killed :llier I week. 7l 5-FU+GSH+G-CSF killed after I week. 
Table (2): Comparison of haematological paramelers and bone matrow cylology in all studied groups versus contiol group.

\begin{tabular}{|c|c|c|c|c|c|c|c|c|c|c|c|}
\hline \multirow[b]{2}{*}{ Croups } & \multirow{2}{*}{ 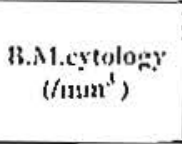 } & \multirow{2}{*}{$\begin{array}{l}11 b \\
(a / s t)\end{array}$} & \multirow{2}{*}{$\begin{array}{l}11(T) \\
(\%)\end{array}$} & \multirow{2}{*}{$\begin{array}{c}\text { MCHC } \\
1 \%)\end{array}$} & \multirow{2}{*}{$\begin{array}{l}M C V \\
\text { (1) }\end{array}$} & \multirow{2}{*}{$\begin{array}{l}\mathrm{MCH} \\
\text { (pog) }\end{array}$} & \multirow{2}{*}{$\underset{(\text { manic }}{\text { Tl.c }}$} & \multicolumn{4}{|c|}{ D1.C $(\%)$} \\
\hline & & & & & & & & Neutrophils & I.yuphuestes & Eosinophils & Mlonocytes \\
\hline $\begin{array}{c}\text { Gp2 } \\
\text { is contral }\end{array}$ & $\stackrel{!}{0.703}$ & $\begin{array}{l}1 \\
0.170\end{array}$ & !) & $\frac{1}{0.50 v}$ & $\begin{array}{c}i \\
0 . S 66\end{array}$ & $\begin{array}{c}1 \\
0.1+1\end{array}$ & $\stackrel{1}{1.500}$ & $\frac{1}{0.18}$ & $\begin{array}{c}i \\
0.145\end{array}$ & $\frac{1}{0.643}$ & $\begin{array}{c}! \\
0.458\end{array}$ \\
\hline $\begin{array}{c}\text { Gp3 } \\
\text { is control }\end{array}$ & $\begin{array}{c}\uparrow \\
0.067 \\
\end{array}$ & $\begin{array}{c}i \\
0.996\end{array}$ & $\begin{array}{c}i \\
0.936\end{array}$ & $\begin{array}{c}! \\
0.305\end{array}$ & $\begin{array}{c}i \\
0.541\end{array}$ & $\frac{1}{0.05 \%}$ & $\begin{array}{c}\uparrow \\
0.002^{* *}\end{array}$ & $\begin{array}{c}1 \\
0.00 .3 * *\end{array}$ & $\begin{array}{c}\uparrow \\
0.002 * *\end{array}$ & $\begin{array}{c}1 \\
0.952\end{array}$ & $\begin{array}{c}1 \\
0.010 * * *\end{array}$ \\
\hline Gp $4 a$ vs contrnt & $\begin{array}{c}1 \\
0.000()_{1 * *}^{*}\end{array}$ & $\begin{array}{c}\downarrow \\
0.336 \\
\end{array}$ & $\frac{1}{0.135}$ & $\begin{array}{c}i \\
1.0 \times 0) \\
\end{array}$ & $\begin{array}{c}i \\
1.000\end{array}$ & $\begin{array}{c}! \\
0.267 \\
\end{array}$ & $\begin{array}{c}1 \\
0.00(0)]^{*: 5}\end{array}$ & 0.1776 & $\underset{0.039 \times}{i}$ & $\frac{1}{0.977}$ & $\begin{array}{c}1 \\
0.175 \\
\end{array}$ \\
\hline $\begin{array}{c}\text { Gp } 5 \mathrm{as} \\
\text { is miters }\end{array}$ & $\begin{array}{c}1 \\
1.0(0) 0\end{array}$ & $\begin{array}{c}1 \\
1.0(1)(6)\end{array}$ & $\frac{1}{0.400}$ & $\begin{array}{c}T \\
0.098 \\
\end{array}$ & (1).952 & $\begin{array}{c}! \\
0.135 \\
\end{array}$ & $\begin{array}{c}i \\
0.987 \\
\end{array}$ & $\begin{array}{c}1 \\
0.459 \\
\end{array}$ & $\underset{0,0)(1 * *}{1}$ & $\frac{1}{0.477}$ & 1 \\
\hline $\begin{array}{c}\text { Gp } 62 \\
\text { vs contral }\end{array}$ & $\begin{array}{c}T \\
0.72 .3 \\
\end{array}$ & $\frac{4}{0 .(1)}=$ & $\begin{array}{c}1 \\
1.000\end{array}$ & (1). $4: 3$ & $\stackrel{!}{0.870}$ & 1). 110 & $\begin{array}{c}\tau \\
0.346 \\
\end{array}$ & $\begin{array}{c}1 \\
0.572 \\
\end{array}$ & $i_{0.646}^{1}$ & $\begin{array}{c}t \\
0.945 \\
\end{array}$ & $\frac{!}{0.755}$ \\
\hline $\begin{array}{c}\left.G_{i}\right) 7 a \\
\text { is control }\end{array}$ & !).o(0)1** & $\stackrel{1}{0.092}$ & 1.000 & $\begin{array}{c}i \\
1 .(6 x)\end{array}$ & $\frac{1}{0.34 s}$ & 0.195 & $0.0001^{* * 3}$ & $\begin{array}{c}1 \\
0.126\end{array}$ & $\begin{array}{c}T \\
0.059 \\
\end{array}$ & $\begin{array}{c}1 \\
0.575 \\
\end{array}$ & $\begin{array}{c}1 \\
0.650 \\
\end{array}$ \\
\hline $\begin{array}{c}\mathrm{Gp} 4 \mathrm{~b} \\
\text { ss control }\end{array}$ & $\left.0.000\right|^{* *}$ & $\begin{array}{c}1 \\
0.993\end{array}$ & $\begin{array}{c}! \\
0.990\end{array}$ & $\begin{array}{c}1 \\
1.000\end{array}$ & $\begin{array}{c}i \\
1.0000\end{array}$ & $\begin{array}{c}! \\
1.1 \mathrm{k}) 0\end{array}$ & $\frac{1}{0.00(0) 1^{* * *}}$ & $\begin{array}{c}! \\
0.0001 * *\end{array}$ & $\begin{array}{c}\uparrow \\
0.0001^{* * 6}\end{array}$ & $\frac{1}{0.99:}$ & $\begin{array}{c}1 \\
0.497\end{array}$ \\
\hline $\begin{array}{c}G_{p} 5 b \\
\text { vs controt }\end{array}$ & $\frac{!}{0.00(1) 1^{\circ * x}}$ & $\frac{1}{0.213}$ & $\begin{array}{c}1 \\
0.244\end{array}$ & $\begin{array}{c}1 \\
1.000\end{array}$ & $\begin{array}{c}! \\
I .0(x)\end{array}$ & $\begin{array}{c}1 \\
1,0(0) \\
\end{array}$ & $\begin{array}{c}1 \\
0.0001 * * \\
\end{array}$ & $\begin{array}{c}\frac{1}{10} \\
0.0013^{* * *}\end{array}$ & $\begin{array}{c}i \\
0.206 \\
\end{array}$ & $\begin{array}{c}1 \\
0.898\end{array}$ & $\begin{array}{c}! \\
0.945\end{array}$ \\
\hline $\begin{array}{c}\text { Gp } 6 \mathrm{~b} \\
\text { vs control }\end{array}$ & $0.1+5$ & $\begin{array}{c}! \\
0.589\end{array}$ & $\frac{1}{2}$ & $\begin{array}{c}1 \\
0.973\end{array}$ & $\begin{array}{c}T \\
0.42) 6\end{array}$ & $\begin{array}{c}! \\
0 .(1) y)\end{array}$ & $\frac{1}{10.006 * *}$ & $\frac{1}{0.040^{*}}$ & $\begin{array}{c}\uparrow \\
0.013 *\end{array}$ & $\frac{1}{0.906}$ & $\begin{array}{c}1 \\
0.405\end{array}$ \\
\hline $\begin{array}{c}\text { Gp Tb } \\
\text { vs control }\end{array}$ & $\underset{1}{1 .(K x) \mid * *}$ & $\begin{array}{c}t \\
0.935\end{array}$ & $\begin{array}{c}1 \\
1.0(x)\end{array}$ & $\begin{array}{c}\downarrow \\
1.0(10)\end{array}$ & $\begin{array}{c}1 \\
0.999\end{array}$ & $\begin{array}{c}1 \\
0.673 \\
\end{array}$ & $\begin{array}{c}! \\
0 .(100) 1 * * \\
\end{array}$ & $0.0001^{* *}$ & $\begin{array}{c}i \\
0.0001^{\text {t* }}\end{array}$ & $\begin{array}{c}\uparrow \\
0.978\end{array}$ & $\frac{1}{0.736}$ \\
\hline & & & * & $\begin{array}{l}\text { hificint } \\
\text { ghly si }\end{array}$ & $\begin{array}{l}P<0 \text {. } \\
\text { ilicant }\end{array}$ & $P<0.0$ & & $\begin{array}{l}i=\text { higher } \\
1=\text { Inwer }\end{array}$ & & & \\
\hline
\end{tabular}


Table (3): Comparison of haematological parameters and bone marrow cytology in mice killed 1 day after receiving: 5-FU (gp 4a), 5-FU preceeded by GSH pretreatment (gp 5a), 5-FU preceeded by G-CSF pretreatment (gp 6a) and 5-FU preceeded by combined GSH and G-CSF pretreatment (gp 7a).

\begin{tabular}{|c|c|c|c|c|c|c|}
\hline & $\begin{array}{c}\text { Gp 5a vs } \\
\text { gp 4a }\end{array}$ & $\begin{array}{c}\text { Gp 6a vs } \\
\text { gp 4a }\end{array}$ & $\begin{array}{c}\text { Gp 6a } \\
\text { vs gp } 5 a\end{array}$ & $\begin{array}{c}G p 7 a \\
v s g p 4 a\end{array}$ & $\begin{array}{c}\text { Gp 7a vs } \\
\text { gp 5a }\end{array}$ & $\begin{array}{c}\text { Gp 7a vs } \\
\text { gp 6a }\end{array}$ \\
\hline $\mathrm{TLC}\left(/ \mathrm{mm}^{3}\right)$ & $0.0001 * *$ & $\begin{array}{c}\uparrow \\
0.0001 * *\end{array}$ & $\begin{array}{c}\uparrow \\
0.911\end{array}$ & $\begin{array}{c}\downarrow \\
1.000\end{array}$ & $\begin{array}{c}\downarrow \\
0.0001 * *\end{array}$ & $0.0001^{* *}$ \\
\hline Neutrophils \% & $\begin{array}{c}1 \\
0.987\end{array}$ & $\begin{array}{c}t \\
0.973\end{array}$ & $\begin{array}{c}1 \\
1.000\end{array}$ & $\begin{array}{c}\uparrow \\
1.000\end{array}$ & $\begin{array}{c}\downarrow \\
0.998\end{array}$ & $\begin{array}{c}1 \\
0.993\end{array}$ \\
\hline Lymphocytes\% & $\begin{array}{c}\downarrow \\
0.977\end{array}$ & $\begin{array}{c}1 \\
0.868\end{array}$ & $\begin{array}{c}1 \\
0.868\end{array}$ & $\begin{array}{c}\downarrow \\
1.000\end{array}$ & $\begin{array}{c}\uparrow \\
0.991\end{array}$ & $\begin{array}{c}\uparrow \\
0.925\end{array}$ \\
\hline Eosinopbiis \% & $\begin{array}{c}\uparrow \\
1.000\end{array}$ & $\begin{array}{c}1 \\
0.608\end{array}$ & $\begin{array}{c}\downarrow \\
0.338\end{array}$ & $\begin{array}{c}\downarrow \\
1.000\end{array}$ & $\begin{array}{c}\downarrow \\
0.999\end{array}$ & $\frac{\downarrow}{0.338}$ \\
\hline Monocytes $\%$ & $\begin{array}{c}\uparrow \\
0.913\end{array}$ & $\begin{array}{c}\uparrow \\
0.983 \\
\end{array}$ & $\begin{array}{c}\downarrow \\
1.000\end{array}$ & $\begin{array}{c}\uparrow \\
0.995\end{array}$ & $\begin{array}{c}1 \\
1.000 \\
\end{array}$ & $\begin{array}{c}\downarrow \\
1.000\end{array}$ \\
\hline Basophils \% & $\begin{array}{c}1 \\
0.662 \\
\end{array}$ & $\begin{array}{c}\downarrow \\
0.998 \\
\end{array}$ & $\begin{array}{c}\uparrow \\
0.972 \\
\end{array}$ & $\begin{array}{c}\downarrow \\
0.662 \\
\end{array}$ & $\begin{array}{c}\downarrow \\
1.000\end{array}$ & $\begin{array}{c}\downarrow \\
0.972\end{array}$ \\
\hline $\mathrm{Hb}(\bar{g} / \mathrm{dl})$ & $\begin{array}{c}\uparrow \\
0.540\end{array}$ & $\begin{array}{c}\uparrow \\
0.549\end{array}$ & $\begin{array}{c}1 \\
1.000\end{array}$ & $\begin{array}{c}\downarrow \\
0.999\end{array}$ & $\begin{array}{c}\downarrow \\
0.189\end{array}$ & $\begin{array}{c}1 \\
0.194 .\end{array}$ \\
\hline HCT $(\%)$ & $\begin{array}{c}\uparrow \\
0.628\end{array}$ & $\begin{array}{c}\uparrow \\
0.257\end{array}$ & $\begin{array}{c}\uparrow \\
0.999\end{array}$ & $\begin{array}{c}\uparrow \\
1.000\end{array}$ & $\begin{array}{c}\top \\
0.263\end{array}$ & $\begin{array}{c}\uparrow \\
0.070\end{array}$ \\
\hline MCHC (\%) & $\begin{array}{c}\uparrow \\
1.000\end{array}$ & $\begin{array}{c}1 \\
0.948\end{array}$ & $\begin{array}{c}1 \\
0.698\end{array}$ & $\begin{array}{c}\downarrow \\
1.000\end{array}$ & $\begin{array}{c}1 \\
0.999\end{array}$ & $\begin{array}{c}\uparrow \\
0.963\end{array}$ \\
\hline $\operatorname{MCV}(\mathrm{fl})$ & $\begin{array}{c}1 \\
0.942\end{array}$ & $\begin{array}{c}1 \\
0.851 \\
\end{array}$ & $\begin{array}{c}1 \\
1.000\end{array}$ & $\begin{array}{c}1 \\
0.997\end{array}$ & $\begin{array}{c}\uparrow \\
1.000\end{array}$ & $\begin{array}{c}\bar{\dagger} \\
0.999 \\
\end{array}$ \\
\hline MCH (pcg) & $\begin{array}{c}1 \\
0.837\end{array}$ & $\begin{array}{c}1 \\
0.928\end{array}$ & $\begin{array}{c}\uparrow \\
1.000\end{array}$ & $\begin{array}{c}\downarrow \\
1.000\end{array}$ & $\begin{array}{c}\uparrow \\
0.903\end{array}$ & $\begin{array}{c}\top \\
0.965\end{array}$ \\
\hline $\begin{array}{l}\text { B.M cytology } \\
\left(/ \mathrm{mm}^{3}\right)\end{array}$ & $\begin{array}{c}\uparrow \\
0.0001^{* *}\end{array}$ & $\begin{array}{c}\uparrow \\
0.0001 * *\end{array}$ & $\begin{array}{c}\uparrow \\
0.411\end{array}$ & $\begin{array}{c}\uparrow \\
1.000\end{array}$ & $\frac{1}{0.0001^{* *}}$ & $\frac{1}{0.0001 * *}$ \\
\hline
\end{tabular}


Table (4): Comparison of hamatological parameters and bone marrow cytology in mice killed 1 week after receiving: 5-FU (group 4b), 5-FU with GSH pretreatment (group 5h). 5-FU with G-CSF pretreatment (group 6b) and 5FU with combined GSH and G-CSF pretreatment (group 7b).

\begin{tabular}{|c|c|c|c|c|c|c|}
\hline 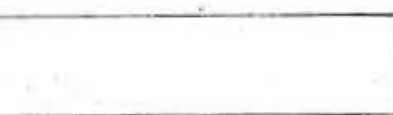 & $\begin{array}{c}\text { Gp } 5 \text { b } \\
\text { vs gp 4b }\end{array}$ & $\begin{array}{c}\text { Gi) } 6 b \\
\text { vs gp } 4 b\end{array}$ & $\begin{array}{c}\mathrm{Gp} 6 \mathrm{~b} \\
\text { vs gp 5b }\end{array}$ & $\begin{array}{c}\mathrm{Gp} 7 \mathrm{~b} \\
\text { vs gp 4b }\end{array}$ & $\begin{array}{c}\text { Gp 7l) } \\
\text { vs gp } 5 b\end{array}$ & $\begin{array}{c}\text { Gp 7b } \\
\text { vs g } 6 b\end{array}$ \\
\hline TLC $\left(/ \mathrm{mm}^{3}\right)$ & $\begin{array}{c}\uparrow \\
0.997\end{array}$ & $\begin{array}{c}\uparrow \\
0.695\end{array}$ & $\begin{array}{c}\uparrow \\
0.961\end{array}$ & $\begin{array}{c}\uparrow \\
1.000\end{array}$ & $\begin{array}{c}\downarrow \\
1.000\end{array}$ & $\begin{array}{c}\downarrow \\
0.803\end{array}$ \\
\hline Neutrophils \% & $\begin{array}{c}\uparrow \\
0.642\end{array}$ & $\begin{array}{c}\uparrow \\
0.414\end{array}$ & $\begin{array}{c}\uparrow \\
1.000\end{array}$ & $\begin{array}{c}\downarrow \\
1.000\end{array}$ & $\begin{array}{c}\downarrow \\
0.642\end{array}$ & $\begin{array}{c}1 \\
0.414\end{array}$ \\
\hline Lymphocytes\% & $\frac{1}{0.779}$ & $\begin{array}{c}1 \\
0.636\end{array}$ & $\begin{array}{c}\downarrow \\
1.000\end{array}$ & $\frac{t}{1.000}$ & $\begin{array}{c}\uparrow \\
0.872\end{array}$ & $\begin{array}{c}\uparrow \\
0.748\end{array}$ \\
\hline Eosinophils \% & $\begin{array}{c}1 \\
1.000\end{array}$ & $\frac{\downarrow}{1.000}$ & $\begin{array}{c}\downarrow \\
1.000\end{array}$ & $\begin{array}{c}\uparrow \\
0.826\end{array}$ & $\begin{array}{c}\uparrow \\
0.553\end{array}$ & $\begin{array}{c}t \\
0.570\end{array}$ \\
\hline Monocytes \% & $\begin{array}{c}\uparrow \\
0.988\end{array}$ & $\begin{array}{c}\uparrow \\
1.000\end{array}$ & $\begin{array}{c}\downarrow \\
0.989\end{array}$ & $\begin{array}{c}\uparrow \\
1.000\end{array}$ & $\begin{array}{c}t \\
0.999\end{array}$ & $\begin{array}{c}\uparrow \\
1 .(x)(x)\end{array}$ \\
\hline Basophils \% & 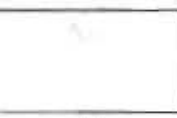 & & & $\begin{array}{c}1 \\
0.915\end{array}$ & & \\
\hline $\mathrm{Hb}(\mathrm{g} / \mathrm{dl})$ & $\begin{array}{c}\downarrow \\
0.986\end{array}$ & $\begin{array}{c}1 \\
1.000\end{array}$ & $\begin{array}{c}\uparrow \\
0.999\end{array}$ & $\frac{1}{1.000}$ & $\begin{array}{c}\uparrow \\
0.999\end{array}$ & $\frac{1}{1.000}$ \\
\hline HC'T (\%) & $\begin{array}{c}\downarrow \\
0.979\end{array}$ & $\begin{array}{c}\downarrow \\
0.975\end{array}$ & $\begin{array}{c}\downarrow \\
1.000\end{array}$ & $\begin{array}{c}\uparrow \\
0.960\end{array}$ & $\begin{array}{c}\uparrow \\
0.330\end{array}$ & $\begin{array}{c}\uparrow \\
0.347\end{array}$ \\
\hline $\mathrm{MCHC}(\%)$ & $\begin{array}{c}\uparrow \\
1.000\end{array}$ & $\begin{array}{c}\downarrow \\
1.000\end{array}$ & $\begin{array}{c}\downarrow \\
0.998\end{array}$ & $\begin{array}{c}\uparrow \\
1.000\end{array}$ & $\begin{array}{c}\downarrow \\
1.000\end{array}$ & $\begin{array}{c}\dagger \\
1.000\end{array}$ \\
\hline $\mathrm{MCV}(\mathrm{fl})$ & $\begin{array}{c}\uparrow \\
1.000\end{array}$ & $\begin{array}{c}\uparrow \\
1.000 \\
\end{array}$ & $\begin{array}{c}\uparrow \\
0.998\end{array}$ & $\begin{array}{c}1 \\
0.987\end{array}$ & $\begin{array}{c}1 \\
1.000\end{array}$ & $\begin{array}{c}1 \\
0.946\end{array}$ \\
\hline $\mathrm{MCH}$ (pcg) & $\begin{array}{c}\uparrow \\
1.000\end{array}$ & $\begin{array}{c}\downarrow \\
0.994\end{array}$ & $\begin{array}{c}1 \\
0.811\end{array}$ & $\begin{array}{c}\downarrow \\
0.986\end{array}$ & $\begin{array}{c}1 \\
0.780\end{array}$ & $\begin{array}{c}1 \\
1.000\end{array}$ \\
\hline B.M cytology $\left(/ \mathrm{mm}^{3}\right)$ & $\begin{array}{c}\uparrow \\
0.305\end{array}$ & $\begin{array}{c}\uparrow \\
0.016^{*}\end{array}$ & $\begin{array}{c}\uparrow \\
0.828\end{array}$ & $\begin{array}{c}\uparrow \\
1.000\end{array}$ & $\begin{array}{c}\downarrow \\
0.388\end{array}$ & $\begin{array}{c}\downarrow \\
\text { (). }(1) 23^{*}\end{array}$ \\
\hline
\end{tabular}

* significant if $\mathrm{P}<0.05$

** highly signiticiant if $P<0.0)$

$\uparrow=$ higher

$\downarrow=$ lower 
Ali et al ...

Table (5): Comparison of hacmalological parancters and bone marrow cytology in mice of groups $4 \mathrm{~b}, 5 \mathrm{~b}, 6 \mathrm{~b}$ and $7 \mathrm{~b}$ ( killed I week after receiving drugs) versus mice of groups $4 a$. $5 a$, Ga and $7 a$ (killed 1 day after recciving drugs).

\begin{tabular}{|c|c|c|c|c|}
\hline & $\begin{array}{c}\text { Gp 4b vs } \\
\text { gp 4a }\end{array}$ & $\begin{array}{c}\text { Gp 5b vs } \\
\text { gp 5a }\end{array}$ & $\begin{array}{c}\text { Gp 6b vs } \\
\text { gp 6a }\end{array}$ & $\begin{array}{c}\text { Gp 7lo vs } \\
\text { gp 7a }\end{array}$ \\
\hline $\operatorname{TLC}\left(/ \mathrm{mm}^{3}\right)$ & $\begin{array}{c}\downarrow \\
0.384\end{array}$ & $\frac{\downarrow}{0.0001 * *}$ & 0.0001 *: & $\begin{array}{c}1 \\
0.527\end{array}$ \\
\hline Neutrophils \% & $\frac{1}{0.026 * *}$ & $\begin{array}{c}1 \\
0.267\end{array}$ & $\begin{array}{c}\downarrow \\
0.663\end{array}$ & $\frac{1}{0.017^{3=}}$ \\
\hline Lymphocytes\% & $\begin{array}{c}\uparrow \\
0.045^{*}\end{array}$ & $\begin{array}{c}\uparrow \\
0.388\end{array}$ & $\begin{array}{c}\uparrow \\
0.346\end{array}$ & $\begin{array}{c}\uparrow \\
0.059\end{array}$ \\
\hline Eosinophils \% & 1.000 & $\begin{array}{c}1 \\
0.999\end{array}$ & $\begin{array}{c}\downarrow \\
0.545\end{array}$ & $\begin{array}{c}\uparrow \\
0.504\end{array}$ \\
\hline Monneytes \% & $\begin{array}{c}1 \\
1.000\end{array}$ & 1.000 & $\begin{array}{c}\downarrow \\
0.988\end{array}$ & 1 \\
\hline Basophils \% & $\begin{array}{c}\uparrow \\
0.447\end{array}$ & & & $\begin{array}{c}t \\
0.718\end{array}$ \\
\hline Ith $(\mathrm{g} / \mathrm{dl})$ & $\begin{array}{c}\uparrow \\
0.999 \\
\end{array}$ & $\begin{array}{c}1 \\
0.944\end{array}$ & $\begin{array}{c}1 \\
0.963\end{array}$ & $\begin{array}{c}\uparrow \\
0.998\end{array}$ \\
\hline HCT (\%) & $\begin{array}{c}\uparrow \\
0.986\end{array}$ & $\frac{1}{0.706}$ & $\begin{array}{c}\downarrow \\
0.428\end{array}$ & $\frac{1}{1.000}$ \\
\hline MCHC (\%) & $\begin{array}{c}\downarrow \\
1.000\end{array}$ & $\begin{array}{c}\downarrow \\
0.992\end{array}$ & $\begin{array}{c}\downarrow \\
1.000\end{array}$ & 1.000 \\
\hline $\operatorname{MCV}(\mathbf{f 1})$ & $\begin{array}{c}\uparrow \\
1.000\end{array}$ & $\begin{array}{c}\uparrow \\
0.989\end{array}$ & $\begin{array}{c}\uparrow \\
0.602\end{array}$ & $\frac{1}{1.000}$ \\
\hline $\mathrm{MCH}(p c g)$ & $\begin{array}{c}\uparrow \\
0.974\end{array}$ & $\begin{array}{c}\uparrow \\
0.146\end{array}$ & $\begin{array}{c}\uparrow \\
0.977\end{array}$ & $\begin{array}{c}\downarrow \\
1.000\end{array}$ \\
\hline B.M cytology (/mm $\left.{ }^{3}\right)$ & $\begin{array}{c}1 \\
0.488\end{array}$ & $0.0001^{* * *}$ & $\frac{1}{0.004 * *}$ & $\begin{array}{c}1 \\
0.376\end{array}$ \\
\hline
\end{tabular}




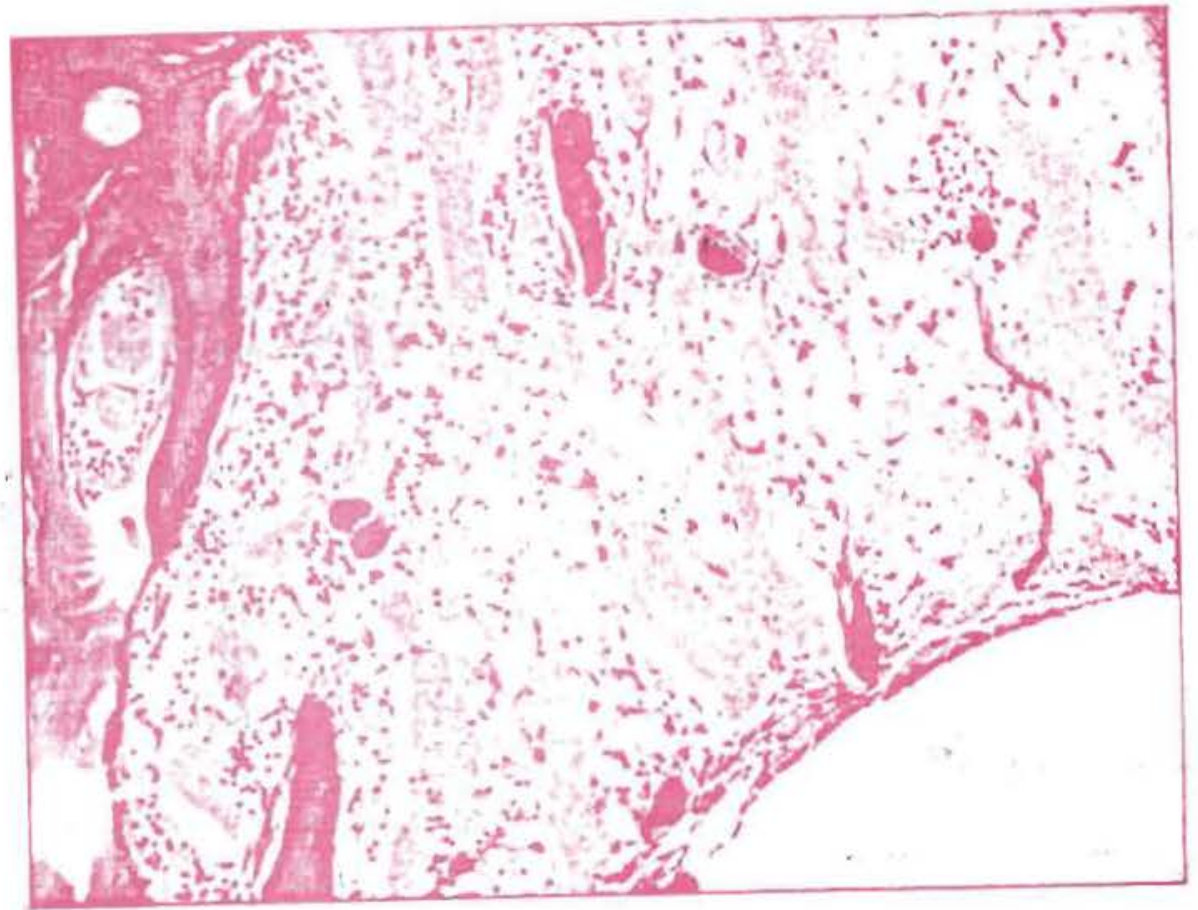

Fig. (1) : A photomicrograph showing severe hypocellularity $(\mathrm{H})$, increased fat content $(F)$, dilated sinusoịds $(S)$ and decreased megakaryocytes in bone marrow of a mouse treated with 5-FU and killed after 1 week (group 4b). (H\&E $\times 100)$.

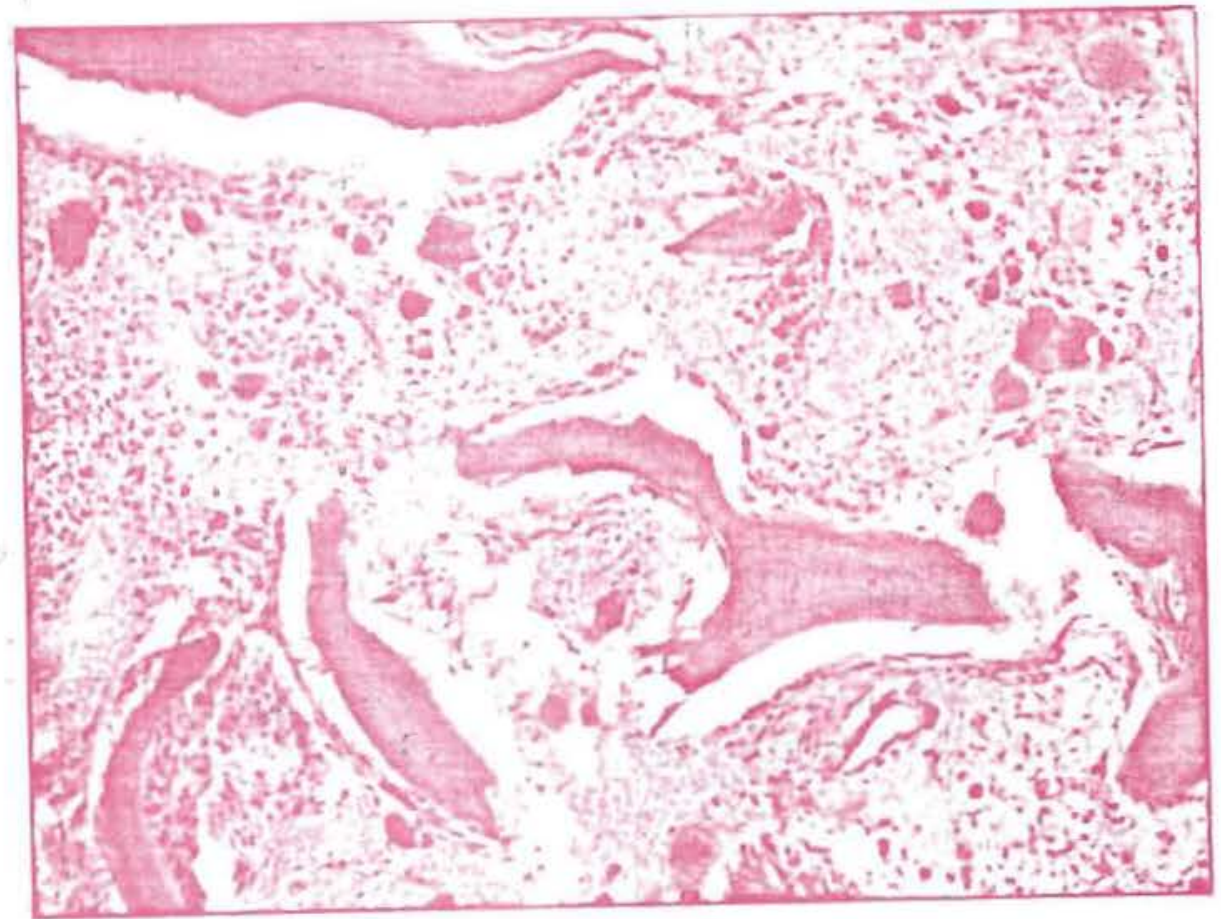

Fig. (2): A photomicrograph showing severe hypocellularity $(\mathrm{H})$, interstitial haemorthage $(\mathrm{IH})$, dilated sinusoids $(\mathrm{S})$ and increased megakaryocytes in bone marrow of a mouse treated with 5-FU and killed after 1 week (group 4b). $(H \& E \times 100)$. 
Ali et al ...

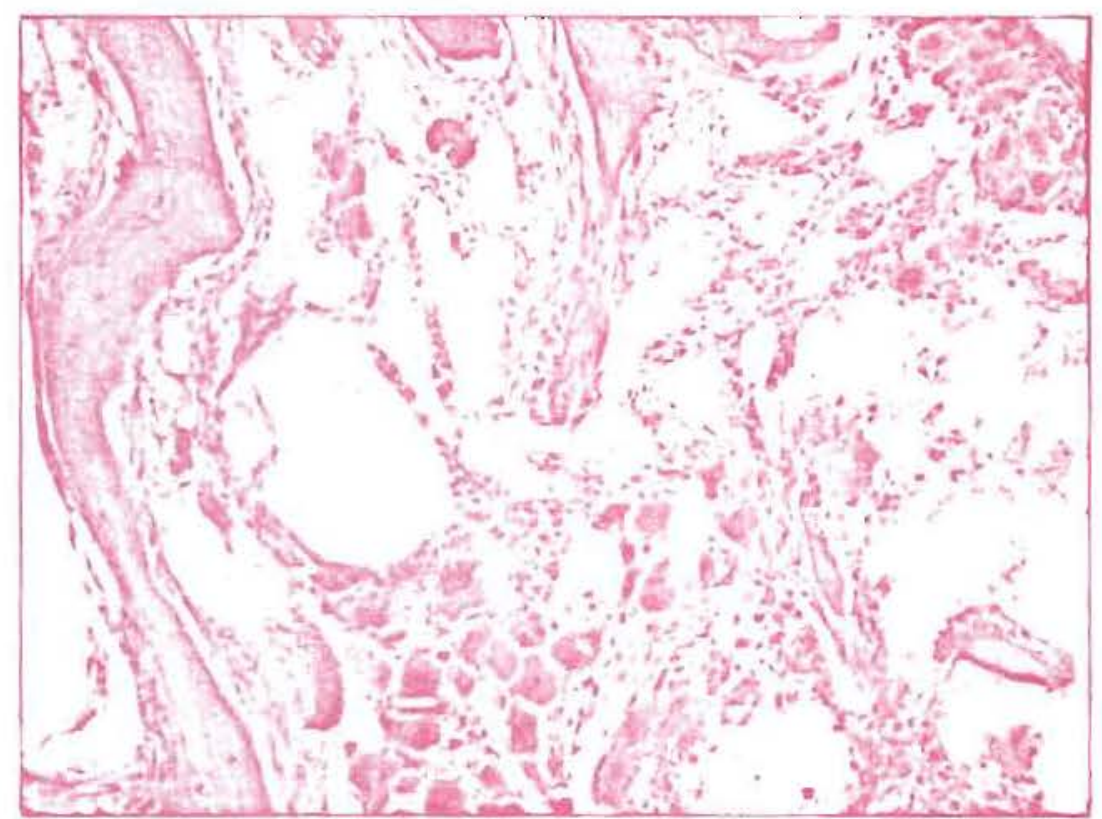

Fig. (3) : A photomicrograph showing severc hypocellularity $(\mathrm{H})$ and interstitial fibrosis (F) in bone marrow of a mouse treated with 5-FU and killed after 1 week (group 4b).

$(H \& E \times 100)$.

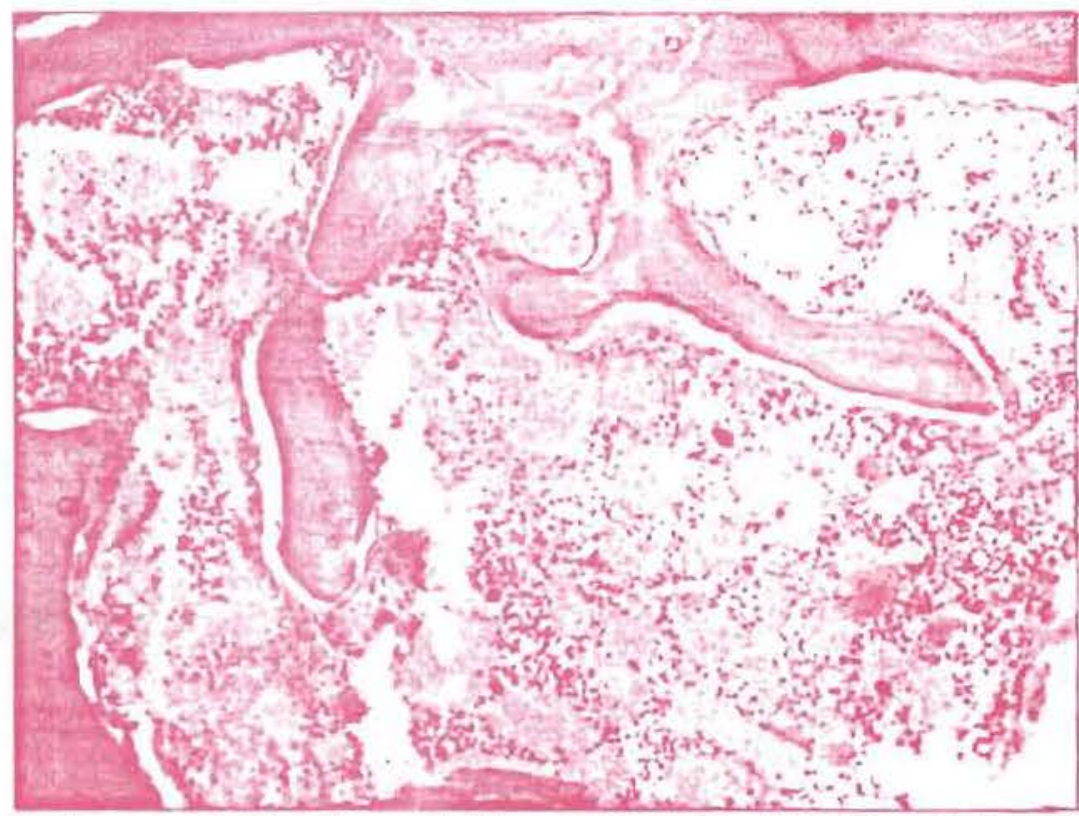

Fig. (4) : A photomicrograph showing mild hypocellularity $(\mathrm{H})$, dilated sinusoids $(\mathrm{S})$, interstitial haemorrhage $(\mathrm{IH})$ and decreased megakaryocytes in bone marrow of a mouse treated with 5-FU + GSH and killed after 1 week (group 5b).

$(H \& E \times 100)$. 


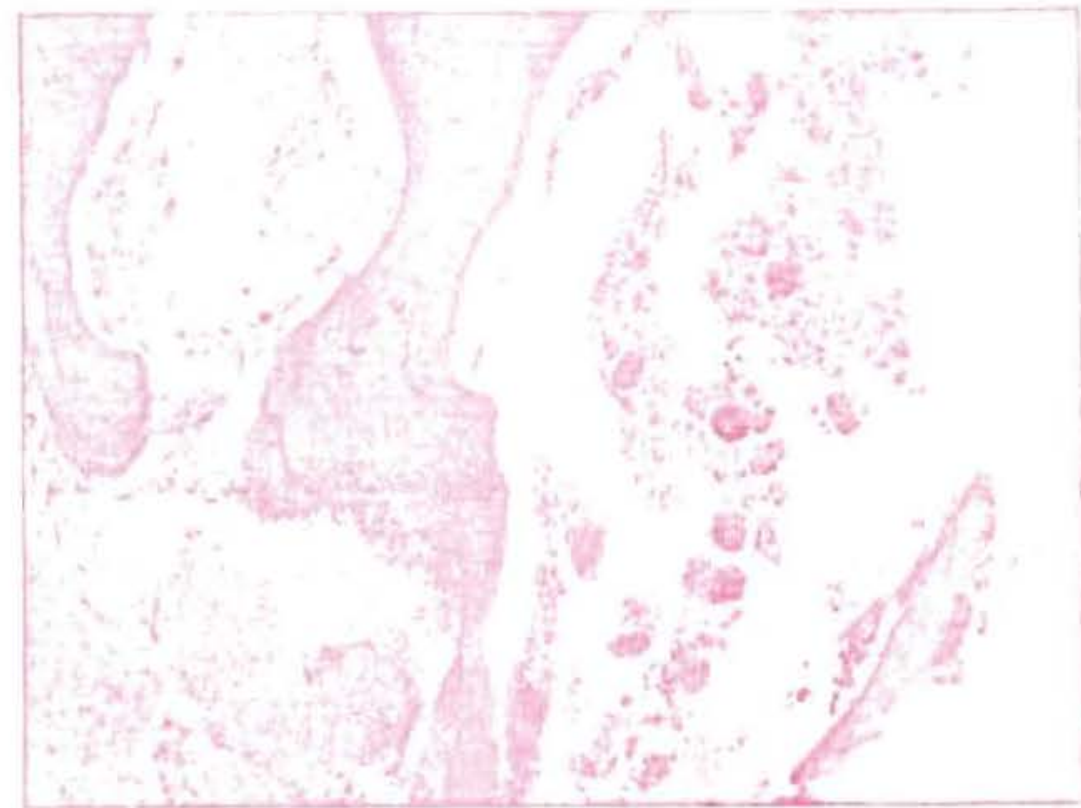

Fig. (5) : A photomicrograph showing mild hypocellularity $(\mathrm{H})$, interstitial haemorrhage (IH) and increased megakaryocytes in bone marrow of a mouse treated with 5FU + G-CSF and killed after 1 week (group 6b). $(H \& E \times 100)$.

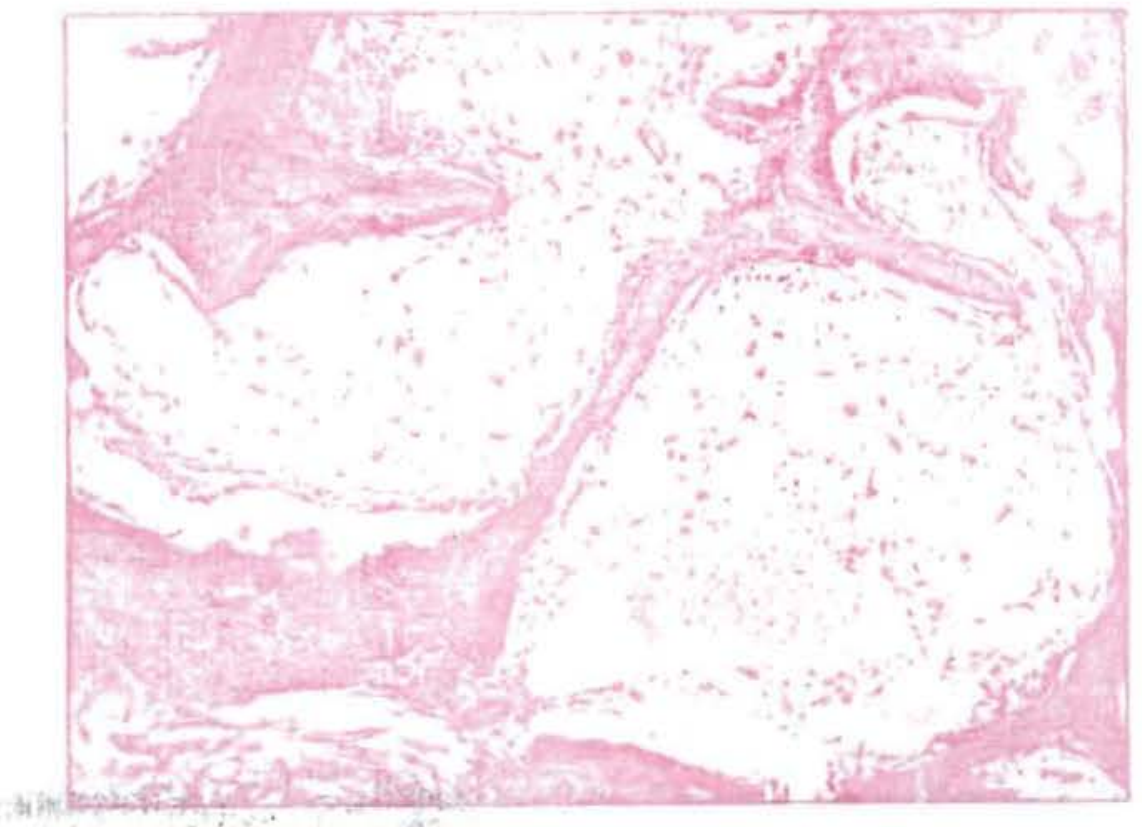

Fig. (6) : A photomicrograph showing severe hypocellularity $(\mathrm{H})$, increased fat content (F) and interstitial haemorrhage (IH) in bone marrow of a mouse treated with 5-FU + GSH + G-CSF and killed after 1 week (group 7b).

$(H \& E \times 100)$. 


\section{REFERENCES}

Anderson, G. and Bancroft, J. (2002): Tissue processing and microtomy. In: Theory and Practice of Histological Techniques. Bancroft, J. and Gamble, M. (Eds.), 5th ed., Churchill Livingstone, London, Edinburgh, New York, Philadelphia, St Louis, Sydney, Toronto, P.P.85-107.

Barrand, M. A.; Bagrij, T, and Neo, S. X. (1997): "Multidrug resistance-associated protein: A protein distinct from Pglycoprotein involved in cytotoxic drug expulsion." Gen. Pharmacol., 28: 639-645.

Brockstein, B.; Haraf, D. J.; Stenson, K.; Sulzen, L.; Witt, M. E; Weichselbaum, R. W. and Vokes, E. E. (2000): "A phase I-If study of concomitant chemoradiotherapy with paclitaxel (one-hour infusion), 5-fluorouracil and hydroxyurea with granulocyte colony stimulating factor support for patients with poor prognosis head and neck cancer." Annals of Oncology, 11:721-728.

Cascinu, S.; Labianca, R.; Alessandroni, P.; Marcellini, M.; Silva, R. R.; Pancera, G.; Testa, E.; Martignoni, G.; Barni, S.; Frontini, L.; Zaniboni, A.; Luporini, G.; Cellerino, R. and Catalano, G. (1997): "Intensive weekly chemotherapy for advanced gastric cancer using 5-fluorouracil, cisplatin, epidoxorubicin, 6S-leucovorin, glutathione and filgrastim: A report from the Italian Group for the Study of Digestive Tract Cancer (GISCAD)." J.C.O., 15: 3313-3319.

Chen, G. and Zeller, W. J. (1991): "Augmentation of cisplatin cytotoxicity in vivo by DL-buthionine sulfoximine in DDP sensitive and resistant rat ovarian tumors and its relation to DNA interstrand cross links." Anticancer Res., 11: 2231-2237.

Colombo, P.; Gunnarsson, K.; Latropoulos, M. and Brugh, M. (2001): "Toxicological testing of cytotoxic drugs." International Journal of Oncology, 19: 1021-1028.

D'souza, U. J. A. and Narayana, K. (2002): "Mechanism of cytotoxicity of Ribavirin in the rat bone marrow and testis." Indian J. Physiol. Pharmacol., 46: 221226.

Dale, D. C. (2003) : "Optimizing the management of chemotherapy induced neutropenia." Clinical Advances in Hernatology \& Oncology, 1: 679-684.

Danforth, D. N.; Cowan, K.; Altemus, R.; Merino, M.; Chow, C.; Berman, A.; Chaudhry, U.; Shriver, C.; Steinberg, S. M. and Zujewski, J. A. (2003): "Preoperative FLAC/GranulocyteColony-Stimulating Factor Chemotherapy for Stage II Breast Cancer: A Prospective Randomized Trial." Annals of Surgical Oncology, 10: 635-644. 
Danysz, A.; Wierzba, K. and Wutkiewicx, M. (1984): "Influence of some sulfhydryl compounds on the antineoplastic effectiveness of 5-fluoro-uracil and 6mercaptopurine." Arch. Immunol. Ther. Exp., 32:345-349.

De Haan, G.; Dontje, B.; Engel, C.; Loeffler, M. and Nijhof, W. (1996): "Prophylactic pretreatment of mice with hematopoirtic growth factors induces expansion of primitive cell compartments and results in protection against 5fluorouracil-induced toxicity." Blood, 87: 4581-4588.

Dill, D. B. and Costill, D. L. (1974); "Calculation of percentage changes in volumes of blood, plasma and red cells in dehydration." J. Appl. Physiol., 37: 247-248.

Dobritzsch, D.; Schneider, G.; Schnackerz, K. D. and Lindqvist, Y. (2001): "Crystal structure of dihydropyrimidine dehydrogenase, a major determinant of the pharmacokinetics of the anticancer drug. 5-fluorouracil." The EMBO Journal, 20: 650-660.

Doeing, D. C.; Borowicz, J. L. and Crockett, E. T. (2003): "Gender dimporphism in differential peripheral blood leukocyte counts in mice using cardiac, tail, foot and saphenous vein puncture methods." B.M.C. Clinical Pathology, 3: 313.
Doolittle, N. D.; Abrey, L. E.; Ferrari, N.; Hall, W. A.; Laws, E. R.; McLendon, R. E.; Muldoon, L. L.; Peereboom, D.; Peterson, D. R.; Reynolds, C. P.; Senter, P. and Neuwelt, E. A. (2002): "Targeted delivery in primary and metastatic brain tumors." Clinical Cancer Research, 8: 1702 1709.

Doyle, C. E.; Mackay, J. M. and Ashby, J. (1993): "Failure of N-acetylcysteine to protect the mouse bone marrow against the clastogenicity of 7,12dimethylbenzanthracene." Mutagenesis, 8: 583-584.

England, J. M. and Bain, B. J. (1976): "Total and differential leukocyte count." Br. J. Haematol., 33: 1.

Friberg, L. E.; Freijs, A.; Sandström, M. and Karlsson, M. O. (2000): "Semiphysiological model for the time course of leukocytes after varying schedules of 5fluorouracil in rats" J.P.E.T., 295 (2): 734740.

Gabrilove, J. L. (1991): Colonystimulating factors: clinical status. In: Biologic Therapy of Cancer. Devita, V.T.; Hellman, S. and Rosenberg, S.T. (Eds.), J.B. Lippincott company, Philadelphia, New York, London, Hagerstown, P.P.445-462.

Gardner, R. V.; McKinnon, E.; Poretta, C. and Leiva, L. (2003): "Hemopoietic 
function after use of IL- 1 with chemotherapy or irradiation." The Journal of Immunology, 171: 1202-1206.

Gate, L.; Majumdar, R. S.; Lurk, A. and Tew, K. D. (2004): "Increased myeloproliferation in glutathione s-transferase $\pi$-deficient mice is associated with a deregulation of JNK and Janus Kinase/ STAT pathways." J. Biol. Chem., 279: 86068616.

Harrison, D. E.; Zsebo, K. M. and Astle, C. M. (1994): "Splenic primitive hematopoietic stem cell (PHSC) activity is enhanced by Steel factor because of PHSC proliferation." Blood, 83: 3146.

Haskell, C. M. (1995) : Principles of cancer chemotherapy. In : Cancer Treatment. Haskell, C.M. and Berek, J.S. (Eds.), 4 th ed., W.B. Saunders Company, Philadelphia, London, Toronto, Montreal, Sydney, Tokyo, P.P.31-57.

Hoagland, H. C. (1992): Hematologic complications of cancer chemotherapy. In: The Chemotherapy Source Book. Perry, M.C. (Ed.), William and Wilkins, Baltimore, Hong Kong, London, Munich, Philadelphia, Sydney, Tokyo, P.P. 301317.

Kojima, S.; Takaba, K.; Kimoto, N.; Takeda, T.; Kakuni, M.; Mizutani, M.; Suzuki, K.; Sato, H. and Hara, T. (2003):
"Protective effects of glutathione on (5FU)-induced myelosuppression in mice." Archives of Toxicology, 77: 285-290.

Lamson, D. W. and Brignall, $M, S$. (2000): "Antioxidants and cancer therapy II: quick reference guide." Altern. Med. Rev., 5:152-163.

Lerza, R.; Bogliolo, G.; Muzzulini, C. and Pannacciulli, I. (1986): "Failure of Nacetylcysteine to protect against cisdichlorodiammineplatinum(II)-induced hematopoietic toxicity in mice." Life Sci., 38: $1795-1800$.

Liang, D. C. (2003): "The role of colonystimulating factors and granulocyte transfusion in treatment options for neutropenia in children with cancer." Pediatr. Drugs, 5 (10): 673-684.

Lord, I. B.; Woolford, L. B. and Molineux, G. (2001): "Kinetics of neutrophil production in normal and neutropenic animals during the response to filgrastim ( $\mathrm{r}$ metHu G-CSF) or filgrastim SD/01 (PEGr-metHu G-CSF)." Clinical Cancer Research, 7(7):2085-2090.

Lowenberg, B.; van Putten, W.; Theobald, M.; Gmür, J.; Verdonck, L.; Sonneveld, P.; Fey, M.; Schouten, H.; de Greef, G。; Ferrant, A.; Kovacsovics, T.; Gratwohl, A.; Daenen, S.; Huijgens, P. and Boogaerts, M. (2003): "Effect of priming 
with granulocyte factor on the outcome of chemotherapy for acute myeloid leukemia." N. Engl. J. Med., 349:743-752.

Malet-Martino, M. and Martino, R. (2002) : "Clinical studies of three oral prodrugs of 5-Fluorouracil (Capecitabine, UFT, S-1): A review." The Oncologist, 7 (4): 288-323.

Neuwelt, E. A.; Pagel, M. A.; Kraemer, D. F.; Peterson, D. R. and Muldoon L. L. (2004): "Bone marrow chemoprotection without compromise of chemotherapy efficacy in a rat brain tumor model." J.P.E.T. 309:594-599.

Prasad, K. N. (2004): "Rationale for using high-dose multiple dietary antioxidants as an adjunct to radiation therapy and chemotherapy." The Journal of Nutrition, 134 (11): 3182S-3184S.

Richard, L. S. (1992): Antimetabolites. In: The Chemotherapy Source Book. Perry, M.C. (Ed.), William and Wilkins, Baltimore, Hong Kong, London, Munich, Philadelphia, Sydney, Tokyo, P.P. 301317.

Riedinger, T. M. and Rodak, B. F. (1998): Quantitative laboratory evaluation of erythrocytes. In: Clinical Hematology Principles, Procedures, Correlations. Steine-Martin, E.A.; Lotspeich-Steininger, C.A. and Koepke, J.A. (Eds.), 2nd ed., Lip- pincott, Philadelphia, New York, P.P.106124.

Sattler, M.; Winkler, T.; Verma, S.; Byrne, C. H.; Shrikande, G.; Salgia, R. and Griffin, J. D. (1999) : "Hematopoietic growth factors signal through the formation of reactive oxygen species." Blood, 93: 2928-2935.

Takatani, H.; Soda, H.; Fukuda, M.; Watanabe, M.; Kinoshita, A.; Nakamura, T. and Okai, M. (1996): "Levels of recombinant human granulocyte colonystimulating factor in serum are inversely correlated with circulating neutrophil counts." Antimicrobial Agents and Chemotherapy, 40 (4): 988-991.

Takimoto, C. and Page, R, (2004) : Principles of chemotherapy. In : Cancer Management. A Multidisciplinary Approach. Pazdur, R.; Hoskins, W.J.; Coia, L.R. and Wagman, L.D. (Eds.), 8th ed., CMP Healthcare Media, P.P. 21-38.

Weiss, A. J. and Lackman, R. D. (2002): "A comparison of human G-CSF and human GM-CSF given concurrently with anti-cancer chemotherapy." Oncology Reports, 9: 945-950.

Zhang, K.; Mack, P. and Wong, K.P. (1998): "Glutathione-related mechanisms in cellular resistance to anticancer drugs." Int. J. Oncol., 12: 871-882. 


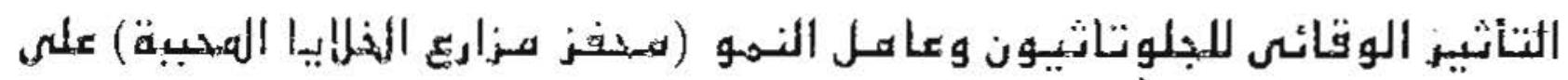

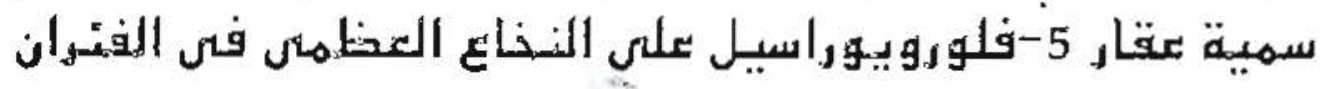

\author{
الشتركين فى البحث
}

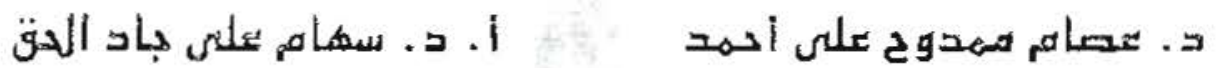

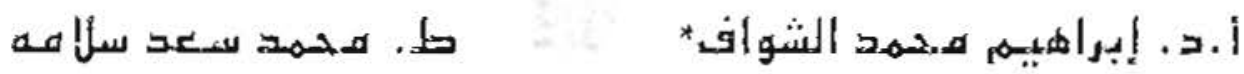 \\ من أتسام الطب الثرعى رالسمر الإكلينبكية والبائرلريى

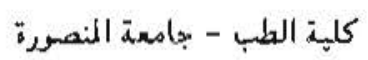

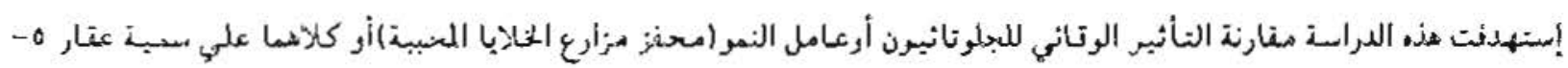

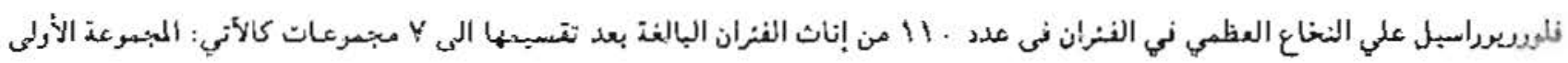

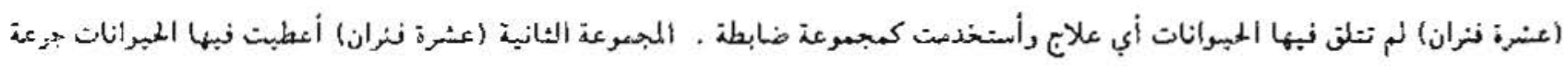

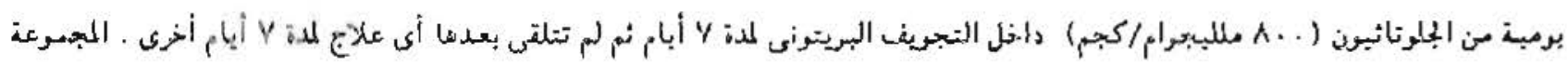

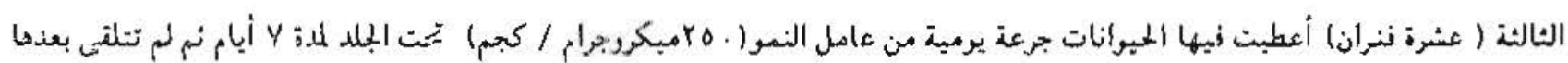

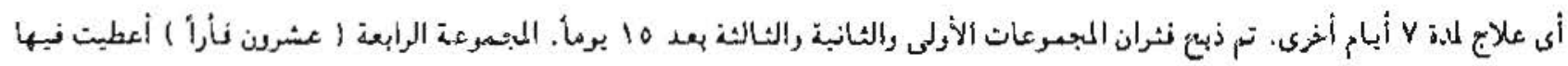

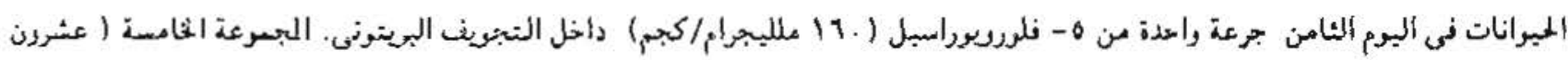

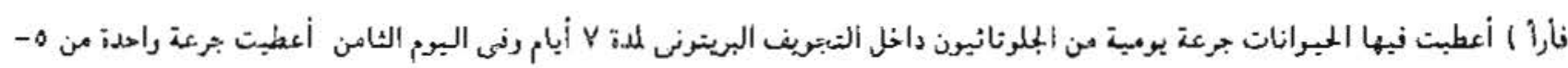

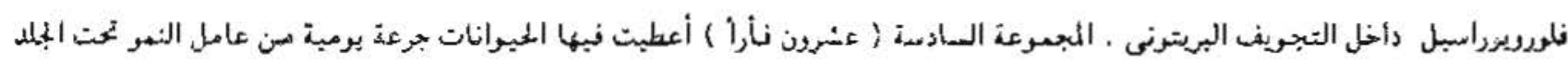

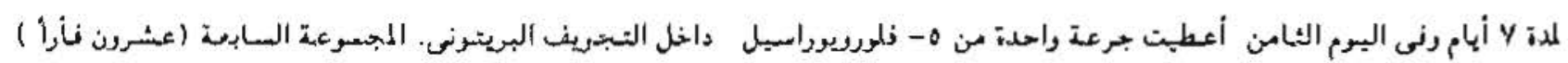

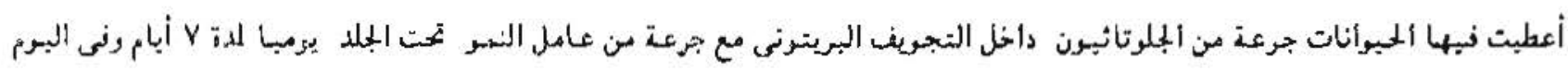

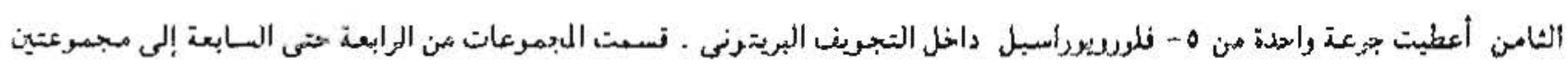

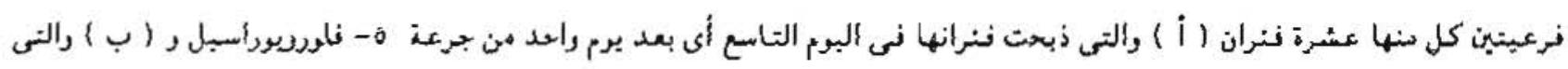

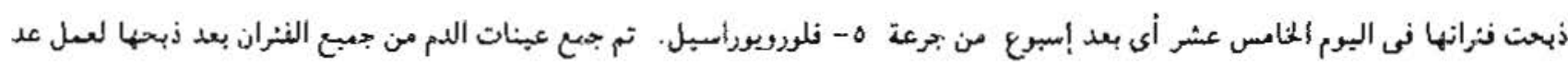

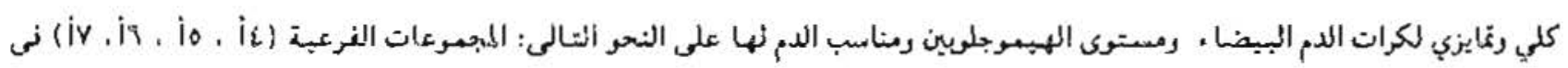

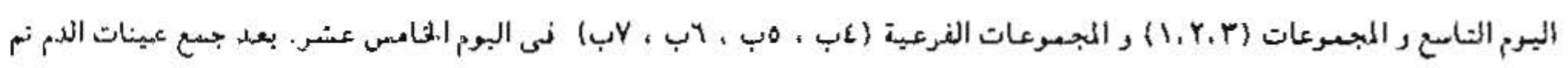




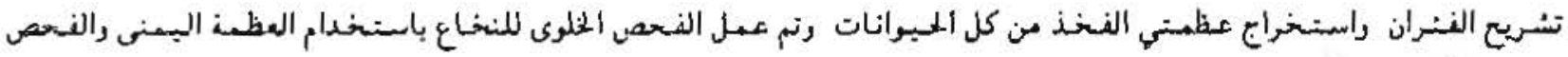

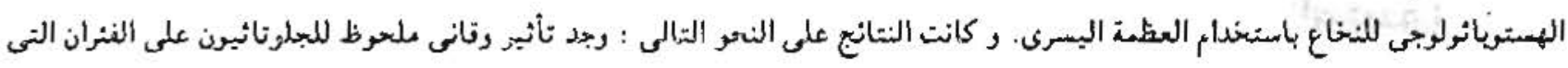

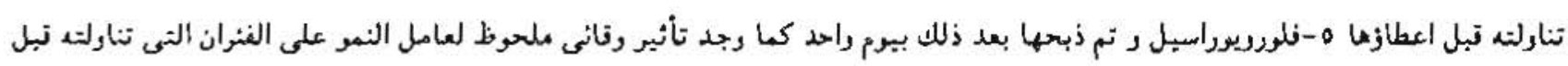

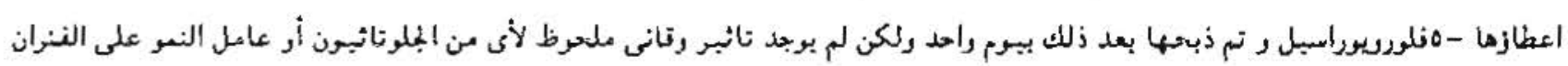

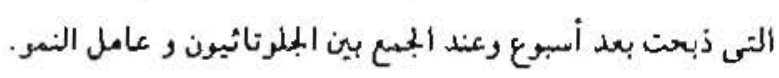

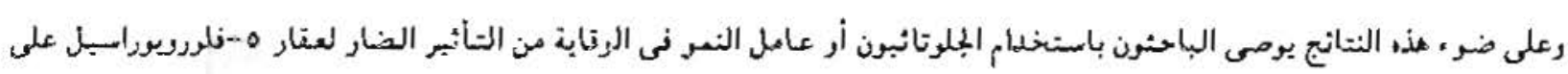

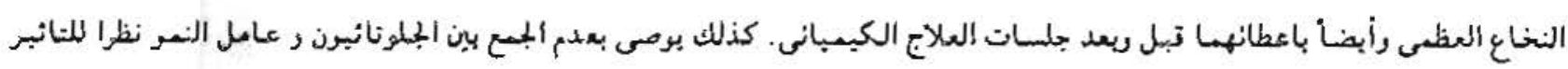

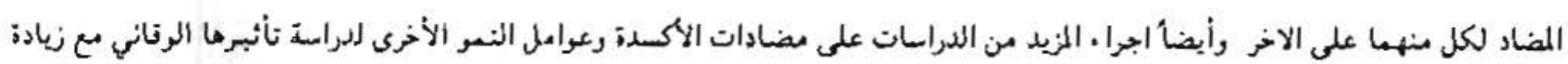
زمن نترة الذرامة. 